\title{
The value of an acute octreotide suppression test in predicting short-term efficacy of somatostatin analogues in acromegaly
}

\author{
Meng Wang 1), 2)* , Ming Shen ${ }^{3), 4)}$ *, Wenqiang He ${ }^{3)}$, Yeping Yang ${ }^{1)}$, Wenjuan Liu ${ }^{1)}$, Yun $\mathrm{Lu}^{5)}$, \\ Zengyi $\mathrm{Ma}^{3}$, Zhao $\mathrm{Ye}^{3)}$, Yichao Zhang ${ }^{3)}$, Xiaolong Zhao ${ }^{1)}$, 4), Bin $\mathrm{Lu}^{1)}$, 4), $\mathrm{Ji} \mathrm{Hu}^{2}$, Yun Huang ${ }^{2)}$, \\ Xuefei Shou ${ }^{3), 4)}$, Yongfei Wang ${ }^{3), 4)}$, Hongying Ye ${ }^{1)}$, 4), Yiming $\mathrm{Li}^{1)}{ }^{1)}$, Shiqi $\mathrm{Li}^{3)}$, 4), Yao Zhao ${ }^{3), 4)}$ \\ and Zhaoyun Zhang ${ }^{1), 4)}$ \\ 1) Department of Endocrinology and Metabolism, Huashan Hospital, Shanghai Medical College, Fudan University, \\ Shanghai 200040, China \\ 2) Division of Endocrinology, the Second Affiliated Hospital, Soochow University, Suzhou 215000, China \\ 3) Department of Neurosurgery, Huashan Hospital, Shanghai Medical College, Fudan University, Shanghai 200040, China \\ 4) Shanghai Pituitary Tumor Center, Shanghai 200040, China \\ 5) Department of Nuclear Medicine, Huashan Hospital, Shanghai Medical College, Fudan University, Shanghai 200040, China
}

\begin{abstract}
Predicting the efficacy of long-acting somatostatin analogues (SSA) remains a challenge. We aim to quantitatively evaluate the predictive value of the octreotide suppression test (OST) in short-term efficacy of SSA in active acromegaly. Sixty-seven newly diagnosed acromegaly patients were assessed with OST. Subsequently, all patients were treated with long-acting SSA for 3 months, followed by reassessment. Nine parameters were tested, including $\mathrm{GH}_{\mathrm{n}}($ the nadir GH during OST), $\Delta \mathrm{GH} 1\left(=\left[\mathrm{GH}_{0 \mathrm{~h}}-\mathrm{GH}_{\mathrm{n}}\right] / \mathrm{GH}_{0 \mathrm{~h}}, \mathrm{GH}_{0 \mathrm{~h}}\right.$ was the baseline $\mathrm{GH}$ during OST), $\Delta \mathrm{GH} 2\left(=\left[\mathrm{GH}_{\mathrm{m}}-\mathrm{GH}_{\mathrm{n}}\right] / \mathrm{GH}_{\mathrm{m}}\right.$, $\mathrm{GH}_{\mathrm{m}}$ was the mean $\mathrm{GH}$ on day curve), $\mathrm{AUC}_{(0-6 \mathrm{~h})}$ (the $\mathrm{GH}$ area under the curve during OST), $\triangle \mathrm{AUC1}\left(=\left[\mathrm{GH}_{0 \mathrm{~h}}-\mathrm{AUC}_{(0-6 \mathrm{~h})}\right] /\right.$ $\left.\mathrm{GH}_{0 \mathrm{~h}}\right), \triangle \mathrm{AUC} 2\left(=\left[\mathrm{GH}_{\mathrm{m}}-\mathrm{AUC}_{(0-6 \mathrm{~h})}\right] / \mathrm{GH}_{\mathrm{m}}\right), \mathrm{AUC}_{(\mathrm{m}-6 \mathrm{~h})}$ (the $\mathrm{GH}$ AUC during OST where $\mathrm{GH}_{\mathrm{m}}$ was used instead of $\left.\mathrm{GH}_{0 \mathrm{~h}}\right)$, $\triangle \mathrm{AUC1}{ }^{\prime}\left(=\left[\mathrm{GH}_{0 \mathrm{~h}}-\mathrm{AUC}_{(\mathrm{m}-6 \mathrm{~h})}\right] / \mathrm{GH}_{0 \mathrm{~h}}\right)$ and $\triangle \mathrm{AUC2}{ }^{\prime}\left(=\left[\mathrm{GH}_{\mathrm{m}}-\mathrm{AUC}_{(\mathrm{m}-6 \mathrm{~h})}\right] / \mathrm{GH}_{\mathrm{m}}\right)$. The Youden indices were calculated to determine the optimal cutoffs to predict the short-term efficacy of SSA. $\triangle \mathrm{GH} 2$ more than $86.83 \%, \triangle \mathrm{AUC} 2$ more than $-57.48 \%$ and $\triangle \mathrm{AUC2}$ ' more than $-57.98 \%$ provided the best predictors of a good GH response (sensitivity $93.8 \%$, specificity $85.7 \%$ ). $\triangle \mathrm{GH} 2$ more than $90.51 \%$ provided the best predictor of a good tumor size response (sensitivity $84.8 \%$, specificity $87.5 \%)$. The percentage fall of $\mathrm{GH}_{\mathrm{n}}(\Delta \mathrm{GH})$ was a better predictive parameter than $\mathrm{GH}_{\mathrm{n}}$. OST showed higher efficiency in predicting the efficacy of octreotide LAR than lanreotide SR. In conclusion, OST is a valid tool to predict both GH and tumor size response to short-term efficacy of SSA in acromegaly, especially for octreotide LAR. $\mathrm{GH}_{\mathrm{m}}$ is better to be used as basal GH than $\mathrm{GH}_{0}$ during OST.
\end{abstract}

Key words: Acromegaly, Pituitary adenomas, Somatostatin analogues, Pre-surgical medical treatment, Acute octreotide suppression test

ACROMEGALY is an insidious disease associated with a 2 to 2.5 times increased mortality risk

Submitted Apr. 5, 2016; Accepted Jun. 5, 2016 as EJ16-0175 Released online in J-STAGE as advance publication Jul. 12, 2016

Correspondence to: Zhaoyun Zhang, M.D., Ph.D., Department of Endocrinology and Metabolism, Huashan Hospital, Shanghai Medical College, Fudan University, 12 Wulumuqi Zhong Road, Shanghai 200040, China. E-mail: zhaoyunzhang@fudan.edu.cn Correspondence to: Yao Zhao, M.D., Ph.D., Department of Neurosurgery, Huashan Hospital, Shanghai Medical College, Fudan University, 12 Wulumuqi Zhong Road, Shanghai 200040, China. E-mail: zhaoyao20151111@126.com

* Meng Wang and Ming Shen contributed equally to this work.

(C) The Japan Endocrine Society
[1]. Control of insulin-like growth factor I (IGF-1), reduction of systemic complications, control of tumor growth, preservation of pituitary function, and extension of life expectancy are the aims of disease management [2-4]. Transsphenoidal surgery has been the first-line therapy for GH-secreting adenomas, but medical therapy is playing an increasingly important role, especially for those patients who are not in remission after surgery or for whom surgery is contraindicated [5]. Somatostatin analogues (SSA) are the most widely used medications for the medical treatment of acromegaly, with biochemical remission (mean GH levels 
$<2.5 \mu \mathrm{g} / \mathrm{L}$ and IGF-1 normalization) rates of approximately 35\% [6-8] and tumor size response (tumor volume shrinkage $>20 \%$ ) rates of $\sim 70 \%$ [9]. SSA are quite expensive, especially in developing countries in which insurance plans that cover prescriptions are not available, such as China, and importantly, some patients are resistant to SSA. So, it is critical to identify those patients who will benefit from SSA to distinguish them from those who will not.

Lamberts et al. initially proposed that acute suppression of GH in response to an octreotide test might predict the long-term efficacy of subcutaneous shortacting octreotide therapy $[10,11]$. Since then, the octreotide suppression test (OST) has become routine practice in many endocrine centers [12], but the value of the OST in predicting long-term response to SSA therapy is still controversial [12-15]. Moreover, shortterm pre-surgical treatment with SSA in macroadenomas has been supported by a few studies and a recent meta-analysis [16], but it is unclear whether or not the OST can predict the efficacy of SSA after a relatively shorter period of usage, e.g. 3 months. In addition, the most frequently used parameter by previous studies was the nadir $\mathrm{GH}\left(\mathrm{GH}_{\mathrm{n}}\right)$ during the OST (shown in Supplementary Table 1), but there might be parameters (such as the percentage fall of the $\mathrm{GH}_{\mathrm{n}}$ during the OST, etc.) which are more accurate in predicting responses to SSA. Therefore, in addition to nadir GH, we examined additional parameters generated from the OST. The aim of our study was to evaluate the value of the OST in predicting the short-term efficacy of SSA therapy in Chinese patients with active acromegaly.

\section{Subjects and Methods}

\section{Patients}

This was a retrospective study of prospectively obtained data from patients seen between July 2012 and August 2014 at a tertiary referral center in the East of China. Sixty-seven newly diagnosed and untreated patients with acromegaly (44 women and 23 men, mean age $42.9 \pm 12.2$ years) were studied. The diagnosis of active disease was based on the clinical features of acromegaly, failure of $\mathrm{GH}$ suppression to below $1 \mu \mathrm{g} / \mathrm{L}$ in response to a $75 \mathrm{~g}$ oral glucose load, serum IGF-1 level above the age-appropriate reference range and radiologic evidence of a pituitary tumor. Contrastenhanced MRI was performed to identify the size and location of pituitary adenomas. Blood sampling was performed every 30 minutes from $0700 \mathrm{~h}$ to $0900 \mathrm{~h}$ in order to obtain the mean $\mathrm{GH}$ on day curve $\left(\mathrm{GH}_{\mathrm{m}}\right)$. A standard 6-hour OST was performed in all patients [13, 17]. In brief, after an overnight fast and baseline $\mathrm{GH}$ blood sampling the next morning, $100 \mu \mathrm{g}$ of octreotide was administered s.c.. Sampling for GH was continued at hourly intervals for 6 hours. Nine parameters $\left(\mathrm{GH}_{\mathrm{n}}, \Delta \mathrm{GH} 1, \Delta \mathrm{GH} 2, \mathrm{AUC}_{(0-6 \mathrm{~h})}, \Delta \mathrm{AUC1}, \Delta \mathrm{AUC} 2\right.$, $\mathrm{AUC}_{(\mathrm{m}-6 \mathrm{~h})}, \triangle \mathrm{AUC1}$ ' and $\triangle \mathrm{AUC2}$ ') were generated from the OST and $\mathrm{GH}_{\mathrm{m}}$ for further evaluation. After 3 months of long-acting SSA therapy (44 patients with octreotide LAR, 20mg every 4 weeks, and 23 patients with lanreotide SR, 40mg every 2 weeks), patients were evaluated at the end of the period that they were treated with the drug. $\mathrm{GH}_{\mathrm{m}}$, IGF-1 and pituitary MRI were performed to evaluate the response to SSA. A good $\mathrm{GH}$ response was defined as a post-treatment $\mathrm{GH}_{\mathrm{m}}$ on $\mathrm{GH}$ day curve $<2.5 \mu \mathrm{g} / \mathrm{L}$ or $>75 \%$ fall compared with the pre-treatment $\mathrm{GH}_{\mathrm{m}}$. This definition was quite consistent with a previous research in which a good GH response was defined as $80 \%$ or more reduction in GH [18]. An IGF-1 reduction of $\geq 50 \%$ or IGF-1 below the upper limit of normal range (ULN) was considered as a good IGF-1 response [19]. A good Tumor size response was defined as tumor volume shrinkage $>20 \%$ [20]. Accordingly, all patients were categorized into $\mathrm{GH}$ responders or non-responders, and tumor size responders or non-responders. Parameters generated from the OST were compared between groups. Cutoff values for predicting the efficacy of short-term SSA were obtained after construction of receiver-operating characteristic (ROC) curves.

\section{Abbreviated parameters and formulas}

$\mathrm{GH}_{0 \mathrm{~h}}$ was the baseline $\mathrm{GH}$ value during the OST. $\mathrm{GH}_{1 \mathrm{~h}}, \mathrm{GH}_{2 \mathrm{~h}}, \mathrm{GH}_{3 \mathrm{~h}}, \mathrm{GH}_{4 \mathrm{~h}}, \mathrm{GH}_{5 \mathrm{~h}}$ and $\mathrm{GH}_{6 \mathrm{~h}}$ were the $\mathrm{GH}$ values from $1 \mathrm{~h}$ to $6 \mathrm{~h}$ during the OST. $\mathrm{GH}_{\mathrm{n}}$ was the nadir GH during the OST. $\Delta \mathrm{GH} 1=\left[\mathrm{GH}_{0 \mathrm{~h}}-\mathrm{GH}_{\mathrm{n}}\right] /$ $\mathrm{GH}_{0 \mathrm{~h}} . \quad \Delta \mathrm{GH} 2=\left[\mathrm{GH}_{\mathrm{m}}-\mathrm{GH}_{\mathrm{n}}\right] / \mathrm{GH}_{\mathrm{m}} . \quad \mathrm{AUC}_{(0-6 \mathrm{~h})}$ was the GH area under the curve (AUC) during the OST. $\mathrm{AUC}_{(0-6 \mathrm{~h})}=\left(\mathrm{GH}_{0 \mathrm{~h}}+\mathrm{GH}_{1 \mathrm{~h}}\right) / 2+\left(\mathrm{GH}_{1 \mathrm{~h}}+\mathrm{GH}_{2 \mathrm{~h}}\right) / 2+$ $\left(\mathrm{GH}_{2 \mathrm{~h}}+\mathrm{GH}_{3 \mathrm{~h}}\right) / 2+\left(\mathrm{GH}_{3 \mathrm{~h}}+\mathrm{GH}_{4 \mathrm{~h}}\right) / 2+\left(\mathrm{GH}_{4 \mathrm{~h}}+\mathrm{GH}_{5 \mathrm{~h}}\right) / 2$ $+\left(\mathrm{GH}_{5 \mathrm{~h}}+\mathrm{GH}_{6 \mathrm{~h}}\right) / 2 . \quad \Delta \mathrm{AUC1}=\left[\mathrm{GH}_{0 \mathrm{~h}}-\mathrm{AUC}_{(0-6 \mathrm{~h})}\right] /$ $\mathrm{GH}_{0 \mathrm{~h}} \cdot \Delta \mathrm{AUC} 2=\left[\mathrm{GH}_{\mathrm{m}}-\mathrm{AUC}_{(0-6 \mathrm{~h})}\right] / \mathrm{GH}_{\mathrm{m}} \cdot \mathrm{AUC}_{(\mathrm{m}-6 \mathrm{~h})}$ was the GH AUC during the OST where $\mathrm{GH}_{\mathrm{m}}$ was used instead of $\mathrm{GH}_{0 \mathrm{~h}}$. $\mathrm{AUC}_{(\mathrm{m}-6 \mathrm{~h})}=\left(\mathrm{GH}_{\mathrm{m}}+\mathrm{GH}_{1 \mathrm{~h}}\right) / 2+$ $\left(\mathrm{GH}_{1 \mathrm{~h}}+\mathrm{GH}_{2 \mathrm{~h}}\right) / 2+\left(\mathrm{GH}_{2 \mathrm{~h}}+\mathrm{GH}_{3 \mathrm{~h}}\right) / 2+\left(\mathrm{GH}_{3 \mathrm{~h}}+\mathrm{GH}_{4 \mathrm{~h}}\right) / 2+$ $\left(\mathrm{GH}_{4 \mathrm{~h}}+\mathrm{GH}_{5 \mathrm{~h}}\right) / 2+\left(\mathrm{GH}_{5 \mathrm{~h}}+\mathrm{GH}_{6 \mathrm{~h}}\right) / 2 . \Delta \mathrm{AUC1}{ }^{\prime}=\left[\mathrm{GH}_{0 \mathrm{~h}^{-}}\right.$ $\left.\mathrm{AUC}_{(\mathrm{m}-6 \mathrm{~h})}\right] / \mathrm{GH}_{0 \mathrm{~h}}$ and $\Delta \mathrm{AUC2}{ }^{\prime}=\left[\mathrm{GH}_{\mathrm{m}}-\mathrm{AUC}_{(\mathrm{m}-6 \mathrm{~h})}\right] /$ 
$\mathrm{GH}_{\mathrm{m}}$. Sensitivity, specificity, positive predictive value (PPV) and negative predictive values (NPV) were calculated as follows: sensitivity $=$ true positives $/$ (true positives + false negatives); specificity $=$ true negatives $/$ (true negatives + false positives); PPV $=$ true positives / (true positives + false positives); NPV $=$ true negatives / (true negatives + false negatives).

\section{Biochemical measurements}

GH was measured by a two-site chemiluminescent immunometric assay AutoDELFIA ${ }^{\circledR}$ hGH (PerkinElmer Life and Analytical Sciences, Wallac Oy, Finland), intra-assay CV: 5.3-6.5\%, inter-assay CV: 5.7-6.2\%, sensitivity: up to $0.01 \mu \mathrm{g} / \mathrm{L}(0.026 \mathrm{mU} / \mathrm{L})$.

IGF-1 was measured with the Immulite 2000 solidphase, enzyme-labeled chemiluminescent immunometric assay (Siemens Healthcare Diagnostic Products Limited, UK), expected values depending on age (1-6 years: $49-327 \mu \mathrm{g} / \mathrm{L}$; $7-11$ years: $57-551 \mu \mathrm{g} / \mathrm{L}$; $12-13$ years: $143-850 \mu \mathrm{g} / \mathrm{L}$; $14-16$ years: $220-996 \mu \mathrm{g} / \mathrm{L}$; $17-18$ years: $163-731 \mu \mathrm{g} / \mathrm{L}$; $19-20$ years: $127-483 \mu \mathrm{g} / \mathrm{L}$; 21-35 years: $115-358 \mu \mathrm{g} / \mathrm{L}$; $36-50$ years: $94-284 \mu \mathrm{g} / \mathrm{L}$; $>50$ years: $55-238 \mu \mathrm{g} / \mathrm{L}$; intra-assay $\mathrm{CV}$ : $2.3-3.5 \%$; inter-assay CV: 7.0-7.1\%; sensitivity: $20 \mu \mathrm{g} / \mathrm{L}$ ). IGF-1 index = IGF-1/ ULN [21].

\section{Magnetic resonance imaging (MRI) studies}

MRI was performed before and 3 months after SSA pre-surgical treatment. Tumor sizes were calculated by the Di Chiro and Nelson formula: volume $=$ height $\times$ length $\times$ width $\times \pi / 6$ [22]. When T2-weighted images were available, the $\mathrm{T} 2$ intensity of the solid portion was visually compared with the cerebral grey and white matter in the adjacent temporal lobe. Pituitary adenoma tissue was classified as being hypointense, when the MRI signal was equal to or lower than white matter and as hyperintense when the signal was equal to or higher than grey matter. An isointense signal was defined as a signal intensity between white and grey matter [23]. Patients with T2-hypointense adenomas were compared with T2-iso/hyperintense adenomas [24].

\section{Statistics analysis}

Data are presented as mean \pm SD (or median with interquartile range) for continuous variables normally (or not normally) distributed, and as frequency for categorical variables. Normality was tested by the ShapiroWilk W test. Statistical analyses of categorical vari- ables were carried out using Chi-square and Fisher's exact tests as appropriate. Means were compared using the Student $t$ test when data distribution was normal, or by Wilcoxon rank-sum (Mann-Whitney) test when variables were not normally distributed. Correlations were performed, and Pearson correlation coefficients, or the Spearman Rank correlation coefficients when variables were normally, or not normally distributed, respectively, are reported. After construction of ROC curves, the Youden indices were calculated to determine the optimal cutoffs for the 9 parameters derived from the OST to predict the short-term efficacy of SSA (sensitivity, specificity, PPV, NPV), which included $\mathrm{GH}_{\mathrm{n}}$, $\Delta \mathrm{GH} 1, \Delta \mathrm{GH} 2, \mathrm{AUC}_{(0-6 \mathrm{~h})}, \Delta \mathrm{AUC1}, \mathrm{AUC2}, \mathrm{AUC}_{(\mathrm{m}-6 \mathrm{~h})}$, $\triangle \mathrm{AUC1}$ ' and $\triangle \mathrm{AUC2}$ '. Linear regression analysis was performed for variables possibly predictive for the outcome of SSA treatment. Statistical evaluation was performed with Statistical software SPSS 16.0. A $p$ value $<0.05$ was considered significant.

\section{Results}

\section{Baseline characteristics}

Clinical information of the 67 patients pre-treatment was presented in Supplementary Table 2. The median pre-treatment $\mathrm{GH}_{\mathrm{m}}$ level was $31.42(16.69 \sim 54.62)$ $\mu \mathrm{g} / \mathrm{L}$. The median post-treatment $\mathrm{GH}_{\mathrm{m}}$ level was 7.00 (2.92 20.48) $\mu \mathrm{g} / \mathrm{L}$. The median percentage fall of $\mathrm{GH}_{\mathrm{m}}$ was $72.18(28.71 \sim 89.26) \%$. The median pre-treatment IGF-1 index was 2.84 (2.35 3.34), which was reduced to $1.98(1.41 \sim 2.47)$ after treatment. The mean percentage reduction of the IGF-1 index was $30.52 \pm 25.24 \%$. Data for volumes were available in 65 cases, which included 62 macroadenomas $(95.38 \%)$ and 3 microadenomas $(4.62 \%)$. The median pre-treatment tumor volume was $2.47(1.62 \sim 5.89) \mathrm{cm}^{3}$. The median posttreatment tumor volume was $1.98(1.11 \sim 4.54) \mathrm{cm}^{3}$. The mean percentage reduction in tumor volume was $21.39 \pm 18.12 \%$. After 3 months of treatment with longacting SSA, 62 patients received surgery, 4 patients were treated with SSA for another 3-9 months followed by surgery, and 1 patient continued with long-acting SSA as primary therapy.

\section{OST}

Values of the 9 parameters derived from the OST were shown in Table 1. Among the 67 patients assessed by the standard 6-hour OST, the median time to reach the $\mathrm{GH}_{\mathrm{n}}$ was $3(2 \sim 5) \mathrm{h}$. The $\mathrm{GH}_{\mathrm{n}}$ occurred 
Table 1 Baseline values of parameters derived from the OST (median with interquartile range)

\begin{tabular}{lc}
\hline Parameter & Median with interquartile range \\
\hline $\mathrm{GH}_{\mathrm{n}}$ & $2.19(0.77 \sim 7.77) \mu \mathrm{g} / \mathrm{L}$ \\
$\Delta \mathrm{GH} 1$ & $89.80(71.37 \sim 95.90) \%$ \\
$\Delta \mathrm{GH} 2$ & $89.81(72.82 \sim 96.83) \%$ \\
$\mathrm{AUC}_{(0-6 \mathrm{~h})}$ & $39.17(19.43 \sim 84.77)$ \\
$\Delta \mathrm{AUC1}$ & $-48.70(-165.75 \sim 7.31) \%$ \\
$\triangle \mathrm{AUC2}$ & $-35.27(-148.67 \sim 16.89) \%$ \\
AUC $_{(\mathrm{m}-6 \mathrm{~h})}$ & $41.40(19.51 \sim 95.94)$ \\
$\Delta \mathrm{AUC1}^{\prime}$ & $-59.51(-190.63 \sim-2.93) \%$ \\
$\triangle \mathrm{AUC2}^{\prime}$ & $-32.27(-151.88 \sim 12.03) \%$ \\
\hline
\end{tabular}

at $1 \mathrm{~h}$ in $16.4 \%$, at $2 \mathrm{~h}$ in $23.9 \%$, at $3 \mathrm{~h}$ in $17.9 \%$, at $4 \mathrm{~h}$ in $16.4 \%$, at $5 \mathrm{~h}$ in $14.9 \%$, and at $6 \mathrm{~h}$ in $10.4 \%$ of the patients. There was no correlation between the time to reach $\mathrm{GH}_{\mathrm{n}}$ and the pre-treatment $\mathrm{GH}_{\mathrm{m}}$ level, pretreatment IGF-1 index or pre-treatment tumor volume ( $p=0.565,0.348,0.774$, respectively). $\mathrm{GH}_{\mathrm{n}}, \mathrm{AUC}_{(0-6 \mathrm{~h})}$ and $\mathrm{AUC}_{(\mathrm{m}-6 \mathrm{~h})}$ was negatively correlated with the reduction of $\mathrm{GH}_{\mathrm{m}}$ and tumor volume. $\Delta \mathrm{GH} 1, \Delta \mathrm{GH} 2$, $\triangle \mathrm{AUC1}, \triangle \mathrm{AUC2}, \triangle \mathrm{AUC1}{ }^{\prime}$ ' and $\triangle \mathrm{AUC2}$ ' was positively correlated with the reduction of $\mathrm{GH}_{\mathrm{m}}$, IGF-1 index and tumor volume. There was no correlation between $\mathrm{GH}_{\mathrm{n}}, \mathrm{AUC}_{(0-6 \mathrm{~h})}, \mathrm{AUC}_{(\mathrm{m}-6 \mathrm{~h})}$ and the reduction of IGF-1 index (Supplementary Table 3).

\section{Linear regression analysis}

$\mathrm{GH}_{\mathrm{n}}, \Delta \mathrm{GH} 1, \Delta \mathrm{GH} 2, \Delta \mathrm{AUC} 1$ and $\triangle \mathrm{AUC} 2$ were also tested in linear regression analysis. We found that $\mathrm{GH}_{\mathrm{m}}$ reduction was strongly associated with $\mathrm{GH}_{\mathrm{n}}, \Delta \mathrm{GH} 1$, $\triangle \mathrm{GH} 2, \triangle \mathrm{AUC} 1$ and $\triangle \mathrm{AUC2}$ when applied individually $\left[\mathrm{GH}_{\mathrm{n}}\left(\right.\right.$ Beta $\left.=-0.517, \mathrm{R}^{2}=0.311, p=0.000\right), \Delta \mathrm{GH} 1$ (Beta $\left.=0.721, \mathrm{R}^{2}=0.538, p=0.000\right), \Delta \mathrm{GH}$ (Beta $=0.711$, $\left.\mathrm{R}^{2}=0.538, p=0.000\right), \Delta \mathrm{AUC1}$ (Beta=0.706, $\mathrm{R}^{2}=0.501$, $\left.p=0.000), \triangle \mathrm{AUC} 2\left(\mathrm{Beta}=0.682, \mathrm{R}^{2}=0.492, p=0.000\right)\right]$, respectively (Supplementary Table 4 ).

\section{Comparison between GH responders/non-responders} and between tumor size responders / non-responders

There were 32 patients assessed as GH responders, 35 as GH non-responders, 33 as tumor size responders and 32 as tumor size non-responders. The $\mathrm{GH}_{\mathrm{n}}$, $\mathrm{AUC}_{(0-6 \mathrm{~h})}$ and $\mathrm{AUC}_{(\mathrm{m}-6 \mathrm{~h})}$ levels were significantly lower in $\mathrm{GH}$ responders than in $\mathrm{GH}$ non-responders $(0.81 \mu \mathrm{g} / \mathrm{L}$ vs $7.27 \mu \mathrm{g} / \mathrm{L}, p<0.0001 ; 25.68$ vs $74.58, p=0.0002 ; 25.5$ vs 74.13, $p=0.0003$; Fig. 1A and Supplementary Fig. 1). The $\triangle \mathrm{GH} 1, \triangle \mathrm{GH} 2, \triangle \mathrm{AUC1} 1, \triangle \mathrm{AUC} 2, \triangle \mathrm{AUC1}{ }^{\prime}$, $\triangle \mathrm{AUC2}$ ' levels were significantly higher in GH responders than in GH non-responders $(95.91 \%$ vs $71.78 \%$,
$96.69 \%$ vs $76.32 \%, 6.44 \%$ vs $-164.90 \%, 16.14 \%$ vs $-137.36 \%,-0.87 \%$ vs $-169.19 \%, 11.62 \%$ vs $-141.23 \%$, all $p<0.0001$, Fig. 1A and Supplementary Fig. 1). Similarly, the $\mathrm{GH}_{\mathrm{n}}, \mathrm{AUC}_{(0-6 \mathrm{~h})}$ and $\mathrm{AUC}_{(\mathrm{m}-6 \mathrm{~h})}$ levels were significantly lower in tumor size responders than in tumor size non-responders $(1.23 \mu \mathrm{g} / \mathrm{L} v s 6.41 \mu \mathrm{g} / \mathrm{L}$, $p<0.0001 ; 28.71$ vs 65.06, $p=0.0108$; 32.1 vs 64.14, $p=0.0191$; Fig. 1B and Supplementary Fig. 2). The $\triangle \mathrm{GH} 1, \triangle \mathrm{GH} 2, \triangle \mathrm{AUC1}, \triangle \mathrm{AUC} 2, \triangle \mathrm{AUC1}{ }^{\prime}$ ' and $\triangle \mathrm{AUC2}$ ' levels were significantly higher in tumor size responders than in tumor size non-responders $(95.16 \%$ vs $73.86 \%$, $95.31 \%$ vs $77.77 \%$, 3.04\% vs $-138.11 \%, 13.76 \%$ vs $-127.61 \%,-5.83 \%$ vs $-146.05 \%, 5.47 \%$ vs $-131.19 \%$, all $p<0.0001$, Fig. 1B and Supplementary Fig. 2).

\section{The predictive value of various parameters derived from the OST for the short-term efficacy of SSA treatment}

The optimal cutoff values of the 9 parameters derived from the OST and $\mathrm{GH}_{\mathrm{m}}$ in predicting a good GH response were shown in Table 2. The cutoff values of $\triangle \mathrm{GH} 2, \triangle \mathrm{AUC} 2$ and $\triangle \mathrm{AUC2}$ ' were $86.83 \%$, $-57.48 \%$ and $-57.98 \%$, respectively, which showed the best power in predicting a good GH response to treatment with SSA, with a PPV of $85.7 \%$ and a NPV of $93.8 \%$ (sensitivity $93.8 \%$ and specificity $85.7 \%$, Fig. $2 \mathrm{~A})$. The cutoff value of $\mathrm{GH}_{\mathrm{n}}$ was $3.37 \mu \mathrm{g} / \mathrm{L}$, with a PPV of $71.8 \%$ and a NPV of $85.7 \%$ (sensitivity $87.5 \%$ and specificity $68.6 \%$, Fig. 2A).

The optimal cutoff values of the 9 parameters in predicting a good tumor size response were shown in Table 3. The cutoff value of $\Delta \mathrm{GH} 2$ was $90.51 \%$, which showed the best power in predicting a good tumor size response to treatment with SSA, with a PPV of $87.5 \%$ and a NPV of $84.8 \%$ (sensitivity $84.8 \%$ and specificity $87.5 \%$, Fig. $2 \mathrm{~B}$ ). The cutoff value of $\mathrm{GH}_{\mathrm{n}}$ was 3.37 $\mu \mathrm{g} / \mathrm{L}$, with a PPV of $71.1 \%$ and a NPV of $77.8 \%$ (sensitivity $81.8 \%$ and specificity $65.6 \%$, Fig. 2B). The cutoff values of $\triangle \mathrm{GH} 1, \triangle \mathrm{AUC} 1, \triangle \mathrm{AUC} 2, \triangle \mathrm{AUC1} 1$ ' and $\triangle \mathrm{AUC2}$ ' were $90.32 \%,-38.9 \%,-42.81 \%,-57.57 \%$ and $-24,57 \%$, respectively, with PPV of $87.1 \%, 84.4 \%$, $84.8 \%, 83.9 \%$ and $87.1 \%$, NPV of $82.4 \%, 81.8 \%$, $84.4 \%, 79.4 \%$, and $82.4 \%$, respectively (Fig. 2 B).

A good IGF-1 response, defined as $\geq 50 \%$ IGF-1 reduction or below the ULN, was achieved in 15 of the 63 patients whose IGF-1 were available before and after SSA treatment. Parameters from the OST did not efficiently separate responders from non-responders with regards to IGF-1 reduction (Supplementary Table 5). 
A

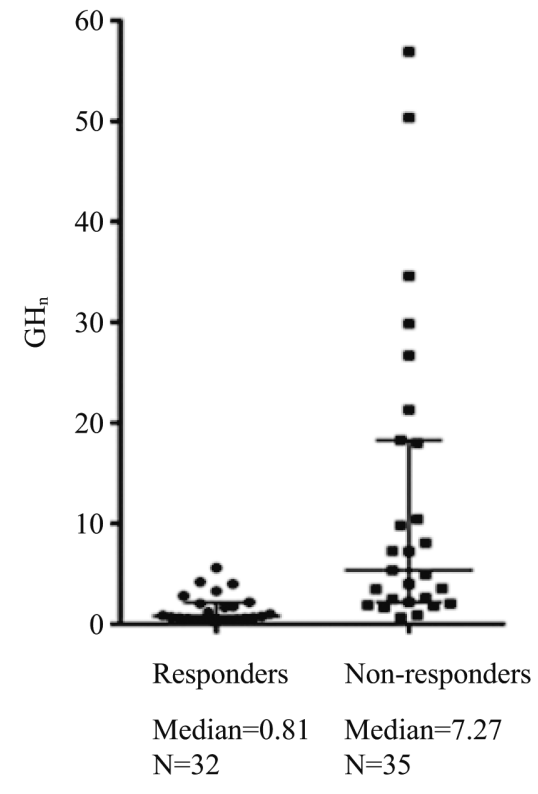

$p<0.0001$

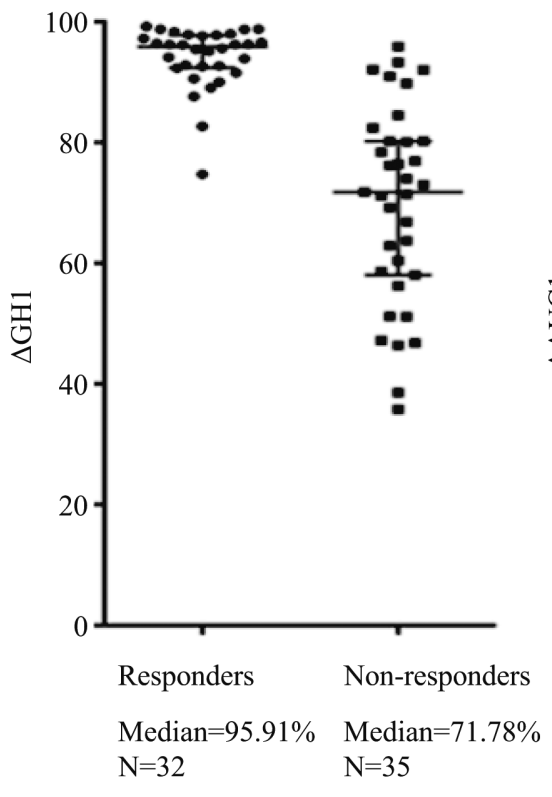

$p<0.0001$

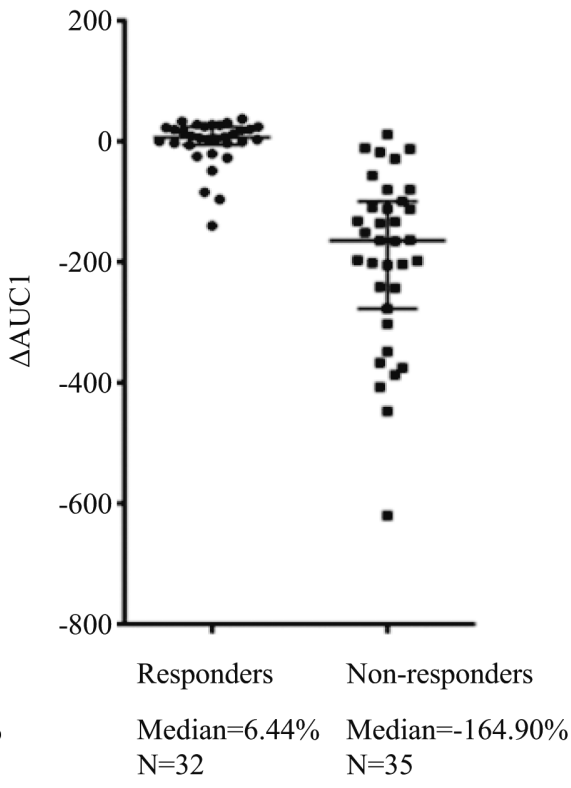

$p<0.0001$

B

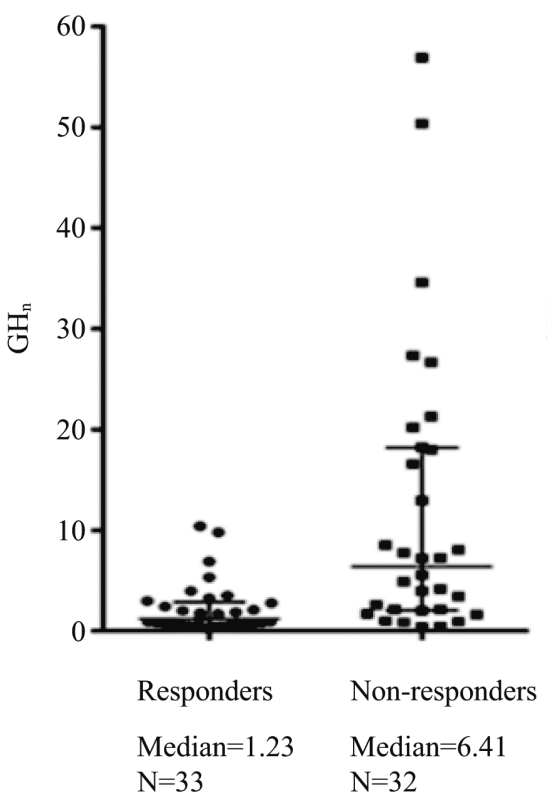

$p<0.0001$

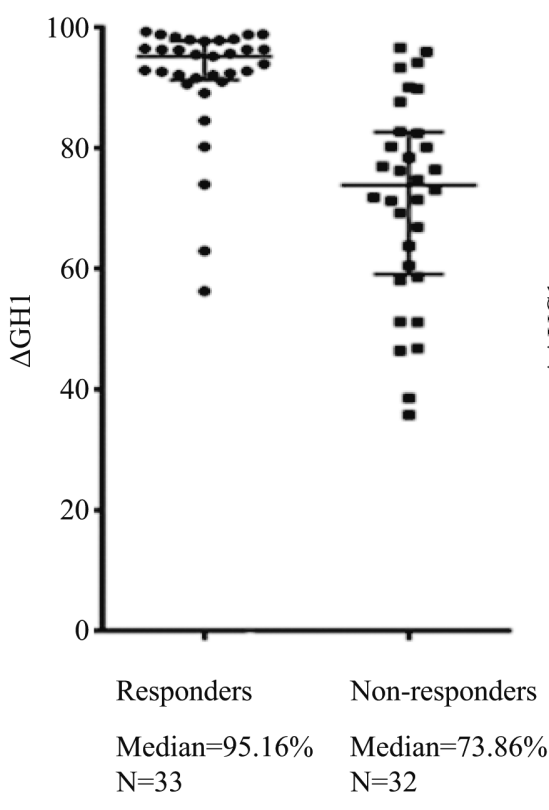

$p<0.0001$

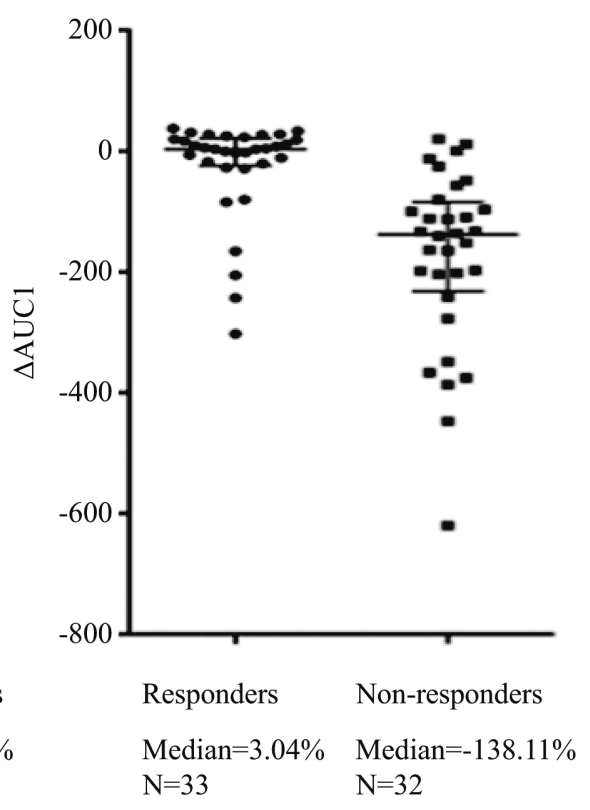

$p<0.0001$

Fig. 1 Comparison of $\mathrm{GH}_{\mathrm{n}}, \Delta \mathrm{GH} 1$ and $\triangle \mathrm{AUC1}$ between $\mathrm{GH}(\mathbf{A})$ and tumor size $(\mathbf{B})$ responders / non-responders $(p<0.0001)$ [Wilcoxon rank-sum (Mann-Whitney) test]. 
Table 2 Optimal cutoff values of parameters derived from the OST in predicting a good GH response (sensitivity, specificity, PPV, NPV)

\begin{tabular}{|c|c|c|c|c|c|c|c|c|}
\hline & $\mathrm{AUC}^{* *}$ & Youden index & Cutoff value & Sensitivity (\%) & Specificity (\%) & PPV (\%) & NPV (\%) & $p$ \\
\hline $\mathrm{GH}_{\mathrm{n}}$ & 0.877 & 0.561 & 3.37 & 87.5 & 68.6 & 71.8 & 85.7 & 0.000 * \\
\hline$\Delta \mathrm{GH} 1$ & 0.946 & 0.769 & $82.57 \%$ & 96.9 & 80.0 & 81.6 & 96.6 & $0.000 *$ \\
\hline$\Delta \mathrm{GH} 2$ & 0.935 & 0.795 & $86.83 \%$ & 93.8 & 85.7 & 85.7 & 93.8 & 0.000 * \\
\hline $\mathrm{AUC}_{(0-6 \mathrm{~h})}$ & 0.763 & 0.420 & 72.31 & 90.6 & 51.4 & 63.0 & 85.7 & $0.000 *$ \\
\hline$\triangle \mathrm{AUC1}$ & 0.947 & 0.763 & $-52.75 \%$ & 90.6 & 85.7 & 85.3 & 90.9 & 0.000 * \\
\hline$\triangle \mathbf{A U C 2}$ & 0.921 & 0.795 & $-57.48 \%$ & 93.8 & 85.7 & 85.7 & 93.8 & $0.000 *$ \\
\hline $\mathrm{AUC}_{(\mathrm{m}-6 \mathrm{~h})}$ & 0.754 & 0.413 & 57.29 & 81.3 & 60.0 & 65.0 & 77.8 & 0.000 * \\
\hline$\triangle \mathrm{AUC1}$ & 0.921 & 0.721 & $-25.41 \%$ & 75.0 & 97.1 & 96.0 & 81.0 & $0.000 *$ \\
\hline$\triangle \mathrm{AUC2}$ & 0.943 & 0.795 & $-57.98 \%$ & 93.8 & 85.7 & 85.7 & 93.8 & 0.000 * \\
\hline
\end{tabular}

${ }^{*} p<0.05$. AUC ${ }^{* *}$, the area under the ROC curve.

A
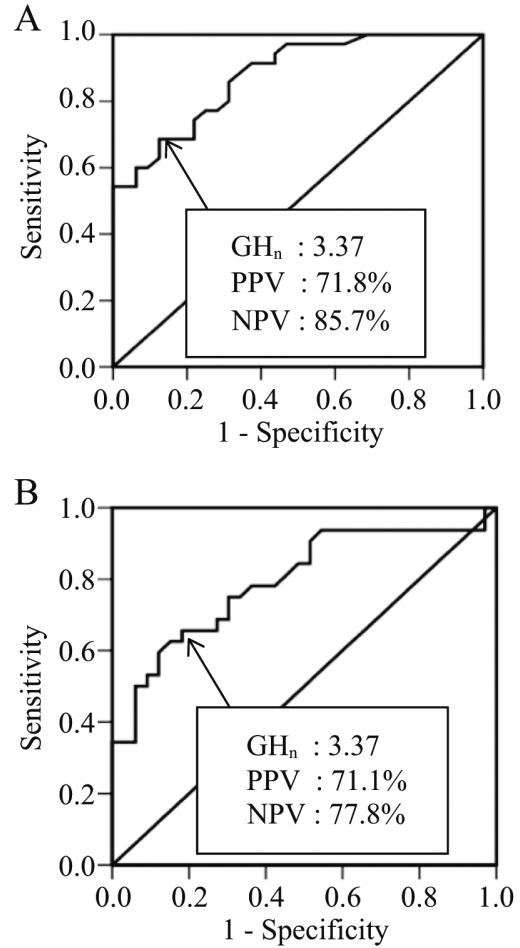
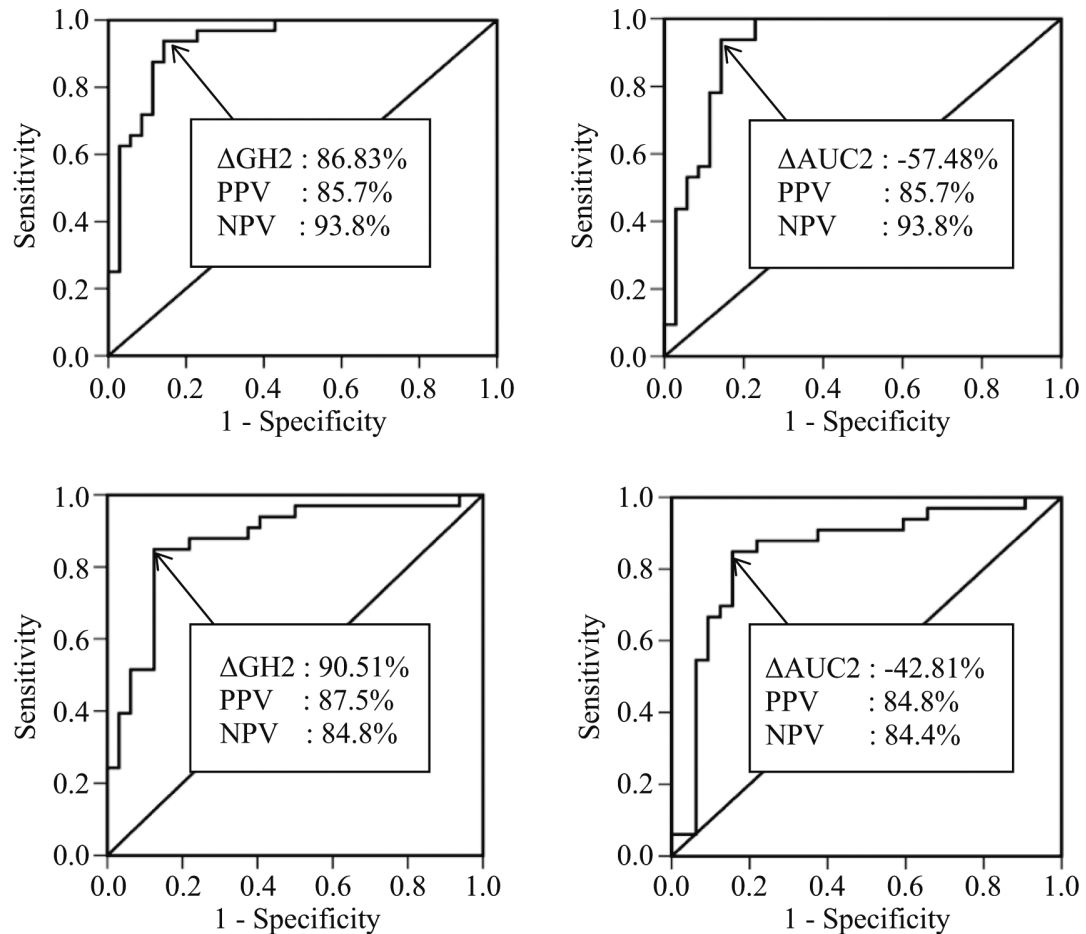

Fig. 2 ROC curve analysis of $\mathrm{GH}_{\mathrm{n}}, \Delta \mathrm{GH} 2$ and $\triangle \mathrm{AUC} 2$ during the OST in predicting a good $\mathrm{GH}$ response (A) and a good tumor size response (B) after treatment with SSA for 3 months.

Table 3 Optimal cutoff values of parameters derived from the OST in predicting a good tumor size response (sensitivity, specificity, PPV, NPV)

\begin{tabular}{|c|c|c|c|c|c|c|c|c|}
\hline & $\mathrm{AUC}^{* *}$ & Youden index & Cutoff value & Sensitivity (\%) & Specificity $(\%)$ & PPV (\%) & NPV (\%) & $p$ \\
\hline $\mathrm{GH}_{\mathrm{n}}$ & 0.794 & 0.474 & 3.37 & 81.8 & 65.6 & 71.1 & 77.8 & 0.000 * \\
\hline$\Delta \mathrm{GH} 1$ & 0.869 & 0.693 & $90.32 \%$ & 81.8 & 87.5 & 87.1 & 82.4 & 0.000 * \\
\hline$\Delta G H 2$ & 0.872 & 0.723 & $90.51 \%$ & 84.8 & 87.5 & 87.5 & 84.8 & $0.000 *$ \\
\hline $\mathrm{AUC}_{(0-6 \mathrm{~h})}$ & 0.683 & 0.349 & 62.12 & 81.8 & 53.1 & 64.3 & 73.9 & $0.000 *$ \\
\hline$\triangle \mathrm{AUC1}$ & 0.848 & 0.662 & $-38.90 \%$ & 81.8 & 84.4 & 84.4 & 81.8 & $0.000 *$ \\
\hline$\triangle \mathrm{AUC2}$ & 0.848 & 0.692 & $-42.81 \%$ & 84.8 & 84.4 & 84.8 & 84.4 & $0.000 *$ \\
\hline $\mathrm{AUC}_{(\mathrm{m}-6 \mathrm{~h})}$ & 0.669 & 0.321 & 57.29 & 75.8 & 56.3 & 64.1 & 69.2 & $0.000 *$ \\
\hline$\triangle \mathrm{AUC1}{ }^{\prime}$ & 0.829 & 0.632 & $-57.57 \%$ & 78.8 & 84.4 & 83.9 & 79.4 & $0.000 *$ \\
\hline$\triangle \mathrm{AUC2}$ & 0.858 & 0.693 & $-24.57 \%$ & 81.8 & 87.5 & 87.1 & 82.4 & 0.000 * \\
\hline
\end{tabular}

${ }^{*} p<0.05 . \mathrm{AUC}^{* *}$, the area under the ROC curve. 
The differential predictive value of $\triangle G H 2$ for the short-term response to octreotide $L A R$ versus lanreotide $S R$

The prognostic profiles of $\Delta \mathrm{GH} 2$ in predicting a good GH and tumor size response to treatment with octreotide LAR versus lanreotide SR were shown in Fig. 3. The cutoff value of $\Delta \mathrm{GH} 2<82.21 \%$ during the OST had a PPV of $92.3 \%$ and a NPV of $94.4 \%$ in predicting a good $\mathrm{GH}$ response in patients treated with octreotide LAR. The PPV and NPV for predicting a good tumor size response was $91.7 \%$ and $84.2 \%$ with the cutoff value of $\Delta \mathrm{GH} 2<90.53 \%$. A less optimal prognostic profile was obtained for subjects treated with Lanreotide SR with the cutoff value of $\Delta \mathrm{GH} 2$ $<86.83 \%$ during the OST providing a PPV of $70 \%$ and a NPV of $100 \%$, in predicting a good GH response. The PPV and NPV for predicting a good tumor size response was $75 \%$ and $85.7 \%$ with the cutoff value of $\Delta \mathrm{GH} 2<89.63 \%$.
The predictive value of age, gender and T2-weighted MRI for the short-term efficacy of SSA treatment

The cutoff value of age was $37.0 \mathrm{y}$ in predicting a good GH response to treatment with SSA, with a PPV of $60.5 \%$ and NPV of $75.0 \%$ (sensitivity $81.3 \%$ and specificity $51.4 \%$, AUC $0.641, p=0.048)$. $45.45 \%(20 / 44)$ female vs $47.83 \%(11 / 23)$ male were GH responders $(p=0.853) . \quad 23.81 \%(10 / 42)$ female $v s 23.81 \%(5 / 21)$ male were IGF-1 responders ( $p=1.000) .51 .16 \%(22 / 43)$ female $v s$ and $50.0 \%(11 / 22)$ male were tumor size responders $(p=0.929)$. T2-weighted MRI was available in 13 subjects. 7 (53.85\%) were hypointense, 2 (15.38\%) were isointense, $4(30.77 \%)$ were hyperintense. $71.43 \%$ (5/7) hypointense adenoma vs $33.33 \%$ (2/6) iso/hyperintense adenoma were $\mathrm{GH}$ responders $(p=0.286) .42 .86 \%$ (3/7) hypointense adenoma vs $0 \%(0 / 6)$ iso/hyperintense adenoma were IGF-1 responders $(p=0.192)$. $71.43 \%$ $(5 / 7)$ hypointense adenoma vs 50.0\% (3/6) iso/hyperintense adenoma were tumor size responders $(p=0.592)$.

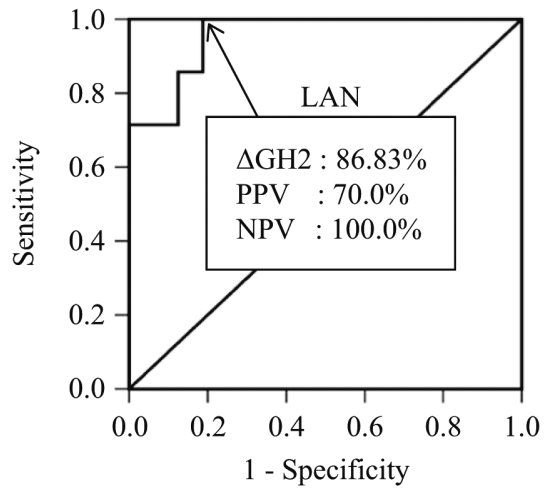

B
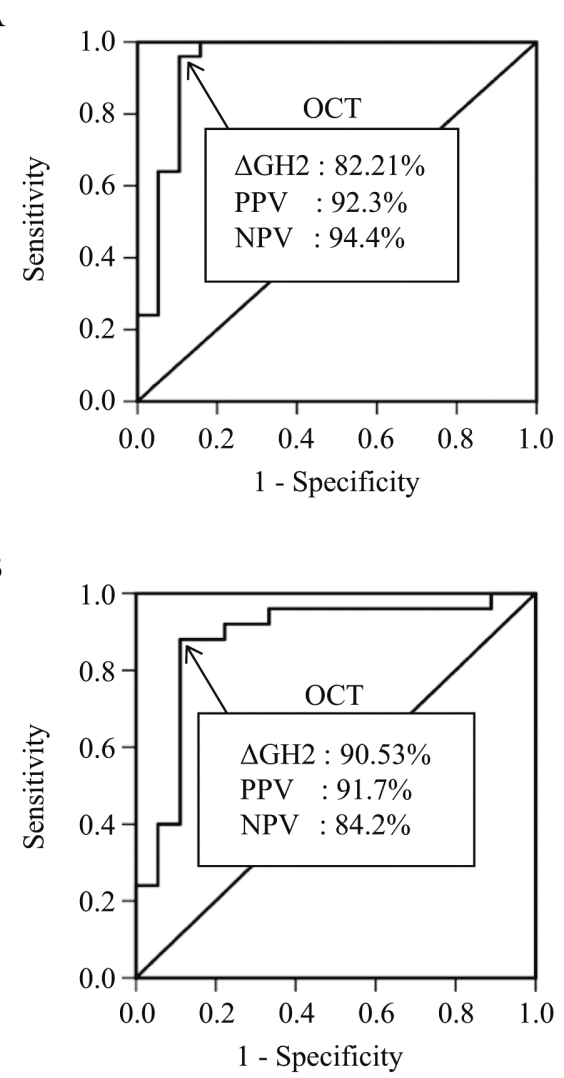

Fig. 3 ROC curve analysis of $\Delta \mathrm{GH} 2$ in predicting a good $\mathrm{GH}$ response (A) and a good tumor size response (B) after treatment with octreotide LAR (OCT) versus lanreotide SR (LAN). 


\section{Discussion}

SSA is a cornerstone of acromegaly management. The value of primary therapy (pre-surgical administration) is controversial, but a recent meta-analysis by Fougner et al. suggested a trend favoring preoperative SSA treatment [16]. However, one third of patients responded poorly or was resistant to SSA [25]. Those patients who are identified as not responding to SSA would receive surgery directly and not use SSA as pre-surgical administration, which will save medical expenses. Factors that have been shown to predict response to SSA include the followings: age, gender, GH level, tumor size, MRI T2 signal, OST, somatostatin receptor (SSTR) phenotype, granular pattern, gsp mutation, Ki-67 expression, SST5TMD4 truncation, arylhydrocarbon-interacting protein (AIP) mutation, zinc finger regulator of apoptosis and cell cycle arrest 1 (ZAC1) expression, E-cadherin expression, and raf kinase inhibitory protein (RKIP) expression [26]. However, most of these factors can be only evaluated by pathology, and the clinical factors are not strong enough predictors to be useful in clinical practice. The OST is one of the most promising methods to predict efficacy of SSA therapy in de novo patients with acromegaly. The OST was first proposed by Lamberts et al. in 1988 to evaluate the suppression extent of short-acting SSA and to help determine the number of injections per day. After the long-acting formulations became available, several studies evaluated the efficacy of OST as a predictor of long-term response (shown in Supplementary Table 1). However, the results of different studies were conflicting, but with more publications in favor of using the OST [13-15, 27-31], than discarding it $[7,12,25,32]$. The conflicting results might be caused by different OST protocols, octreotide dosages, outcome criteria and various parameters selected for evaluation. The purpose of our study was to investigate the predictive value of the OST using rigorous and homogenous methods.

Various OST protocols have been used in different centers. For example, the doses of octreotide used were 50 to $300 \mu \mathrm{g}$, while the sampling time was from 3 to 10 hours. Originally, the OST was performed with $50 \mu \mathrm{g}$ octreotide s.c. and lasted for 6 to 10 hours. Later, Biermasz et al. performed a shorter test (hourly sampling $\times 3$ hours after i.v. administration of $50 \mu \mathrm{g}$ of octreotide) [14] and concluded that 2 hours were sufficient. In our study, the median time to reach the $\mathrm{GH}_{\mathrm{n}}$ was $3(2 \sim 5)$ h. 39 cases $(58.2 \%)$ needed 3 hours to reach the $\mathrm{GH}_{\mathrm{n}}$ and 28 cases (41.8\%) needed 4-6 hours to reach the $\mathrm{GH}_{\mathrm{n}}$. From the results of our study, we conclude that 6 hours are required to determine the nadir GH in most cases.

Most criteria for long-term efficacy of SSA reported in the literature were set with mean $\mathrm{GH}<2.5 \mu \mathrm{g} / \mathrm{L}$ with or without IGF-1 normalization. Based on our previous finding [33], long-term administration of SSA made the tumor texture harder, facilitating both the formation of pseudocapsules and subsequent surgical removal. However, it would be a surgical obstacle if the tumor texture were too fibrotic. Therefore, we have adopted the relatively short-term (3 months) administration of pre-surgical SSA for acromegaly management. The aim of pre-surgical SSA treatment is the achievement of satisfactory GH reduction and tumor shrinkage, the latter making surgical removal easier and safer, rather than the complete remission of the disease. In our study, a good $\mathrm{GH}$ response was defined as a post-treatment $\mathrm{GH}_{\mathrm{m}}$ on $\mathrm{GH}$ day curve $<2.5 \mu \mathrm{g} / \mathrm{L}$ or $>75 \%$ reduction compared with the pre-treatment $\mathrm{GH}_{\mathrm{m}}$, a good IGF-1 was considered as $\geq 50 \%$ IGF-1 reduction or below the ULN [19] and a good tumor size response was defined as the tumor volume shrinkage $>20 \%$ [20]. The definition of a good GH response in our study was quite consistent with a previous research in which a good GH response was defined as $80 \%$ or more reduction in GH [18].

As indicated in Supplementary Table 1, the widely used parameters in the literature were either nadir $\mathrm{GH}$ $(1 \mu \mathrm{g} / \mathrm{L}, 2 \mu \mathrm{g} / \mathrm{L}, 2.5 \mu \mathrm{g} / \mathrm{L}$ or $5 \mu \mathrm{g} / \mathrm{L}$ as cutoff value) or percentage reduction of $\mathrm{GH}(50 \%$ or $75 \%$ as cutoff) during the OST, with PPVs ranging from $33 \% \sim 100 \%$, and NPVs ranging from $46 \% \sim 100 \%$, which were not well enough to predict the efficacy of SSA. Cutoff values for nadir GH were inconsistent in different studies $[13,30]$, and the predictive value of the percent reduction of GH during the OST was scarcely evaluated. In addition, most studies of OST aimed to predict the biochemical response to SSA, instead of tumor size response. There has been only one study which examined the value of OST in predicting tumor size response. The study found that neither acute nor longterm octreotide effects on GH levels were associated with degree of tumor size reduction [7]. As delineated in Supplementary Table 1, among the 13 papers published from 1988 to 2011, there was a great degree of inconsistency, which has led to conflicting conclusions. 
In addition, distinct from previous studies, our study focused on predicting the short-term efficacy, instead of long-term efficacy, which differentiated it from other studies. Furthermore, we have tested the second largest cohort to date, and we used more accurate and rigorous parameters than in previous studies, as shown in Tables 2 and 3.

In our study, the cutoffs were determined for maximal predictive value of both the $\mathrm{GH}_{\mathrm{n}}$ and the percentage reduction in $\mathrm{GH}_{\mathrm{n}}(\Delta \mathrm{GH} 1)$ during the OST. $\Delta \mathrm{GH} 2$ was generated when $\mathrm{GH}_{\mathrm{m}}$ was used as the baseline $\mathrm{GH}$, instead of using $\mathrm{GH}_{0 \mathrm{~h}}$. In order to utilize as much information as possible from the OST curve, we generated $\mathrm{AUC}$ values $\left[\mathrm{AUC}_{(0-6 \mathrm{~h})}\right.$ and $\left.\mathrm{AUC}_{(\mathrm{m}-6 \mathrm{~h})}\right]$ and their relative transformations $(\triangle \mathrm{AUC} 1, \triangle \mathrm{AUC} 2$, $\triangle \mathrm{AUC1}$ ' and $\triangle \mathrm{AUC2}$ '). The predictive values of the various parameters generated from the OST were separately evaluated for both $\mathrm{GH}$ and tumor size response to the short-term administration of pre-surgical SSA therapy. As indicated in Table 2 and Table 3, the delta values were significantly more efficient than $\mathrm{GH}_{n}$ and AUC in predicting the efficacy of pre-surgical SSA therapy. Compared with other parameters, $\triangle \mathrm{GH} 2$, $\triangle \mathrm{AUC2}$ and $\triangle \mathrm{AUC2}$ ' showed higher PPV and NPV ( $85.7 \%$ and $93.8 \%$, respectively) in predicting a good $\mathrm{GH}$ response. In addition, $\Delta \mathrm{GH} 2$ had higher positive and negative predictive values than the other 8 parameters in predicting a good tumor size response (PPV $87.5 \%$ and NPV 84.8\%). According to our study we recommend $\Delta \mathrm{GH} 2$ as the best parameter to predict both $\mathrm{GH}$ and tumor size response to short-term efficacy of SSA in acromegaly, which is very useful for clinicians who are faced with decisions about whether to use an SSA in patients with acromegaly preoperatively. Not surprisingly, the 9 parameters derived from the OST did not reach a high enough efficacy in predicting IGF-1 response, possibly due to the long half-life of IGF-1 and short observation (3 months) of our study. Gadelha et al. summarized that there were at least 3 factors (age, gender, MRI T2W signal), which would be assessed before operation, could predict the efficacy of SSA. We also tested these factors in our cohort, and found that only the age cutoff of $37 y$ could predict a good GH response to some extent (sensitivity $81.3 \%$, specificity $51.4 \%$, PPV $60.5 \%$, NPV 75\%, AUC 0.641, $p=0.048$ ), but the efficiency was obviously lower than the OST. Neither Gender nor MRI T2W signal could distinguish SSA responders from non-responders. This result conflicts with Heck et al.'s [34], possibly due to the small size of the present study (MRI T2W signal was only available in 13 patients). Whether MRI T2W signal could predict the efficacy of SSA needs further evaluation. Interestingly, our data revealed that OST is more useful in predicting the efficacy of octreotide LAR than lanreotide SR, which is supported by the result of a previous study [13].

Our study is the first to use AUC and delta AUC to predict the efficacy of SSA pre-surgical treatment to aid in decision making with regard to acromegaly management. Although the sample size of the cohort in our study is one of the largest (only inferior to Colao et al. [17]) in the literature, more patients are still needed to evaluate if $\triangle \mathrm{AUC}$ values are superior to the traditional parameters $\left(\mathrm{GH}_{\mathrm{n}}\right.$ and $\left.\Delta \mathrm{GH}\right)$ or not.

In conclusion, the OST is a clinically useful test to predict short-term efficacy of SSA treatment with predictive values greater than $85 \%$ (even $>90 \%$ to predict the efficacy of octreotide LAR alone). Compared with $\mathrm{GH}_{0}$, Mean $\mathrm{GH}$ on day curve $\left(\mathrm{GH}_{\mathrm{m}}\right)$ is better to be used as basal GH during the OST. The percentage reduction of $\mathrm{GH}_{\mathrm{n}}(\Delta \mathrm{GH})$ and $\triangle \mathrm{AUC}$ are better predictive parameters than the $\mathrm{GH}_{\mathrm{n}}$ and $\mathrm{AUC}$ and capture information from the entire OST time curve. Whether or not the $\triangle \mathrm{AUC}$ values are superior to the traditional parameters $\left(\mathrm{GH}_{\mathrm{n}}\right.$ and $\left.\Delta \mathrm{GH}\right)$ needs further evaluation.

\section{Acknowledgments}

The authors thank Dr. Karen Klahr Miller for participating in modification the manuscript. This study was supported by the following grants: from National Natural Science Foundation of China (No. 81370938, No.81172391, No.81370884, No.81471041), Sheng Kang Hospital Development Center (SHDC12012220), Shanghai Rising-Star Tracking Program (12QH1400400), Shanghai Municipal Commission of Health and Family Planning (XYQ2011002, XYQ2013120).

\section{Conflict of Interest}

None of the authors have any potential conflicts of interest associated with this research. 
Supplementary Table 1 Prediction of long-term response to SSA by the OST. Review of the literature.

\begin{tabular}{|c|c|c|c|c|c|c|c|c|}
\hline \multirow{2}{*}{$\begin{array}{l}\text { Author \& } \\
\text { year }\end{array}$} & \multirow{2}{*}{$\begin{array}{l}\text { Test dose \& } \\
\text { time }\end{array}$} & \multirow{2}{*}{ Study types } & \multirow{2}{*}{ No. } & \multicolumn{2}{|c|}{ Long-term treatment } & \multirow{2}{*}{ OST positive criteria } & \multirow{2}{*}{$\begin{array}{l}\text { Predictive value } \\
\text { of the OST }\end{array}$} & \multirow{2}{*}{ Conclusion } \\
\hline & & & & Duration & Goal & & & \\
\hline $\begin{array}{l}\text { Lamberts [10] } \\
1988\end{array}$ & $\begin{array}{l}50 \mu g \text { s.c., } \\
10 \mathrm{~h}\end{array}$ & Retrospective & 15 & 96 weeks & $\begin{array}{l}\text { Decrease in mean GH } \\
\text { \& normal IGF-1 }\end{array}$ & Not mentioned & Not mentioned & $\begin{array}{l}\text { Useful for s.c. } \\
\text { octreotide }\end{array}$ \\
\hline $\begin{array}{l}\text { Colao }[17] \\
1996\end{array}$ & $\begin{array}{l}100 \mu g \text { s.c. } \\
6 \mathrm{~h}\end{array}$ & Retrospective & 68 & 1-3 months & $\mathrm{GH}<5 \mu \mathrm{g} / \mathrm{L}$ & mean GH $50 \%$ fall & $\begin{array}{l}\text { PPV } 43 \% \\
\text { NPV } 78 \%\end{array}$ & Not recomme \\
\hline
\end{tabular}

$\begin{array}{ll}\text { Jenkins [27] } & \begin{array}{l}50,100 \text { and } \\ 200 \mu g \text { s.c., Prospective } \quad 6 \quad 6 \text { months } \quad<5 \mathrm{mU} / \mathrm{L}(2.5 \mu \mathrm{g} / \mathrm{L}) \quad \text { Nadir GH }<5 \mathrm{mU} / \mathrm{L}(2.5 \mu \mathrm{g} / \mathrm{L}) \quad \text { Not mentioned } \\ 10 \mathrm{~h}\end{array}\end{array}$

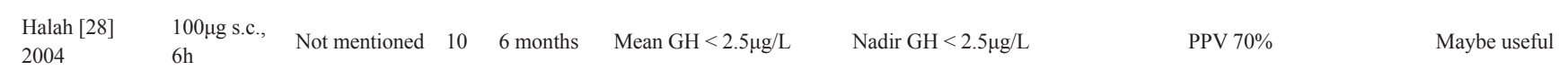

\begin{tabular}{|c|c|c|c|c|c|c|c|c|}
\hline $\begin{array}{l}\text { Lindsay [15] } \\
2004\end{array}$ & $\begin{array}{l}50 \text { or } \\
100 \mu \mathrm{g} \text { s.c., } \\
8 \mathrm{~h}\end{array}$ & Not mentioned & 23 & 3 years & $\begin{array}{l}\mathrm{GH}<5 \mathrm{mU} / \mathrm{L}(2.5 \mu \mathrm{g} / \mathrm{L}) \\
\& \text { normal IGF-1 }\end{array}$ & $\begin{array}{l}\text { nadir } \mathrm{GH}<5 \mathrm{mU} / \mathrm{L}(2.5 \mu \mathrm{g} / \mathrm{L}) \\
\text { nadir } \mathrm{GH}<10 \mathrm{mU} / \mathrm{L}(5 \mu \mathrm{g} / \mathrm{L})\end{array}$ & $\begin{array}{l}\text { PPV } 57 \%(\mathrm{GH}<5 \mathrm{mU} / \mathrm{L}) \\
14 \%(\text { normal IGF1) } \\
\text { PPV 50\% }(\mathrm{GH}<5 \mathrm{mU} / \mathrm{L}) \\
33 \%(\text { normal IGF1) }\end{array}$ & Useful \\
\hline $\begin{array}{l}\text { De Herder [32] } \\
2005\end{array}$ & $\begin{array}{l}50 \mu \mathrm{g} \text { s.c., } \\
465 \mathrm{~min}\end{array}$ & Not mentioned & 24 & $\begin{array}{l}\text { At least } 9 \\
\text { months }\end{array}$ & Normal IGF-1 & $\begin{array}{l}\text { mean GH } 50 \% \text { fall } \\
\text { mean } \mathrm{GH} 75 \% \text { fall } \\
\text { nadir } \mathrm{GH}<1.1 \mu \mathrm{g} / \mathrm{L} \\
\text { nadir } \mathrm{GH}<2 \mu \mathrm{g} / \mathrm{L}\end{array}$ & $\begin{array}{l}\text { PPV } 58 \% \text { NPV } 100 \% \\
\text { PPV } 73 \% \text { NPV } 77 \% \\
\text { PPV } 65 \% \text { NPV } 69 \% \\
\text { PPV } 82 \% \text { NPV } 46 \%\end{array}$ & Not recommended \\
\hline $\begin{array}{l}\text { Karavitaki [13] } \\
2005\end{array}$ & $\begin{array}{l}100 \mu g \text { s.c., } \\
6 \mathrm{~h}\end{array}$ & Not mentioned & 30 & 6 months & $\mathrm{GH}<5 \mathrm{mU} / \mathrm{L}(2.5 \mu \mathrm{g} / \mathrm{L})$ & $\begin{array}{l}\text { Nadir } \mathrm{GH}<5.25 \mathrm{mU} / \mathrm{L}(2.125 \mu \mathrm{g} / \mathrm{L}) \\
\text { (octreotide) } \\
\text { or }<6.05 \mathrm{mU} / \mathrm{L}(3 \mu \mathrm{g} / \mathrm{L}) \text { (lanreotide) }\end{array}$ & $\begin{array}{l}\text { PPV } 94 \% \\
\text { NPV } 100 \% \text { (octreotide) } \\
\text { PPV } 92 \% \\
\text { NPV } 67 \% \text { (lanreotide) }\end{array}$ & $\begin{array}{l}\text { Reliable for } \\
\text { octreotide }\end{array}$ \\
\hline
\end{tabular}

\begin{tabular}{|c|c|c|c|c|c|c|c|c|}
\hline $\begin{array}{l}\text { Gilbert [29] } \\
2005\end{array}$ & $\begin{array}{l}50 \mu \mathrm{g} \text { s.c., } \\
6 \mathrm{~h}\end{array}$ & Retrospective & 33 & 15 months & $\mathrm{GH}<5 \mathrm{mU} / \mathrm{L}(2.5 \mu \mathrm{g} / \mathrm{L})$ & nadir $\mathrm{GH}<5 \mathrm{mU} / \mathrm{L}(2.5 \mu \mathrm{g} / \mathrm{L})$ & $\begin{array}{l}\text { sensitivity } 80 \% \\
\text { specificity } 83 \%\end{array}$ & Useful \\
\hline $\begin{array}{l}\text { Biermasz [14] } \\
2005\end{array}$ & $\begin{array}{l}50 \mu \mathrm{g} \text { i.v., } \\
3 \mathrm{~h}\end{array}$ & Not mentioned & 18 & $\begin{array}{l}4.1 \pm 0.4 \\
\text { years }\end{array}$ & $\begin{array}{l}\mathrm{GH}<5 \mathrm{mU} / \mathrm{L}(2.5 \mu \mathrm{g} / \mathrm{L}) \\
\& \text { normal IGF-1 }\end{array}$ & $\begin{array}{l}\text { nadir } \mathrm{GH}<5 \mathrm{mU} / \mathrm{L}(2.5 \mu \mathrm{g} / \mathrm{L}) \\
\operatorname{nadir} \mathrm{GH}<2.5 \mathrm{mU} / \mathrm{L}(1.25 \mu \mathrm{g} / \mathrm{L})\end{array}$ & $\begin{array}{l}\text { PPV } 73 \% \\
\text { NPV 57\% } \\
\text { PPV } 80 \% \\
\text { NPV } 63 \%\end{array}$ & Useful \\
\hline
\end{tabular}

\begin{tabular}{|c|c|c|c|c|c|c|}
\hline $\begin{array}{l}\text { Pokrajac [12] } \\
2006\end{array}$ & $\begin{array}{l}50 \text { or } \\
100 \mu g \text { s.c., } \\
9 \mathrm{~h}\end{array}$ & Not mentioned & 42 & 2 years & $\begin{array}{l}\mathrm{GH}<5 \mathrm{mU} / \mathrm{L}(2.5 \mu \mathrm{g} / \mathrm{L}) \\
\& \text { normal IGF-1 }\end{array}$ & $\begin{array}{l}\text { nadir } \mathrm{GH}<5 \mathrm{mU} / \mathrm{L}(2.5 \mu \mathrm{g} / \mathrm{L}) \\
\text { mean } \mathrm{GH} 50 \% \text { fall } \\
\text { mean } \mathrm{GH} 75 \% \text { fall }\end{array}$ \\
\hline
\end{tabular}

PPV $82 \& 83 \%$

NPV $50 \& 61 \%$

PPV $69 \& 68 \%$

NPV $38 \& 50 \%$

PPV $72 \& 72 \%$

NPV 40 \& $47 \%$

\begin{tabular}{|c|c|c|c|c|c|c|c|c|}
\hline $\begin{array}{l}\text { Halperin [30] } \\
2008\end{array}$ & $\begin{array}{l}100 \mu g \text { s.c., } \\
6 \mathrm{~h} / 2 \mathrm{~h}\end{array}$ & Retrospective & 18 & 12 months & $\begin{array}{l}\text { IGF-1 }<2 \text { SD } \\
\text { IGF-1 }<3 \text { SD }\end{array}$ & $\begin{array}{l}\text { nadir } \mathrm{GH}<3.6 \mu \mathrm{g} / \mathrm{L} \\
\text { nadir } \mathrm{GH}<9.2 \mu \mathrm{g} / \mathrm{L}\end{array}$ & $\begin{array}{l}\text { PPV } 33 \% \text { NPV } 89 \% \\
\text { PPV } 75 \% \text { NPV } 67 \%\end{array}$ & Useful \\
\hline
\end{tabular}

\begin{tabular}{|c|c|c|c|c|c|c|c|c|}
\hline $\begin{array}{l}\text { Bandgar [31] } \\
2010\end{array}$ & $\begin{array}{l}50 \mu \mathrm{g} \text { s.c., } \\
6 \mathrm{~h}\end{array}$ & Prospective & 10 & 12 months & $\begin{array}{l}\text { Nadir } \mathrm{GH}<1 \mu \mathrm{g} / \mathrm{L} \\
\& \text { normal IGF-1 }\end{array}$ & nadir $\mathrm{GH}<1 \mu \mathrm{g} / \mathrm{L}$ & $\begin{array}{l}\text { PPV } 100 \% \text { NPV } 100 \% \\
\text { PPV } 100 \% \text { NPV } 83.3 \%\end{array}$ & Useful \\
\hline $\begin{array}{l}\text { Carlsen [7] } \\
2011\end{array}$ & $\begin{array}{l}50 \mu \mathrm{g} \text { s.c., } \\
4 \mathrm{~h}\end{array}$ & Prospective & 31 & 6 months & $\begin{array}{l}\mathrm{GH}<2 \mathrm{mU} / \mathrm{L} \\
\& \text { normal IGF-1 }\end{array}$ & mean GH $50 \%$ fall & $\begin{array}{l}\text { Predict GH reduction, but } \\
\text { not tumor shrinkage }\end{array}$ & Not recommended \\
\hline
\end{tabular}


Supplementary Table 2 Patients' data and GH and tumor size parameters before and after short-term pre-surgical therapy with SSA

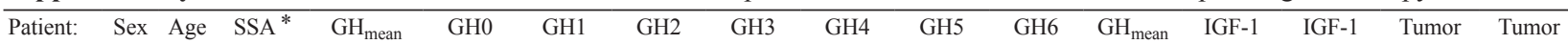
$\begin{array}{lllllllllllllll}\text { (no.) } & (\mathrm{y}) & \text { pre-SSA } & (\mu \mathrm{g} / \mathrm{L}) & (\mu \mathrm{g} / \mathrm{L}) & (\mu \mathrm{g} / \mathrm{L}) & (\mu \mathrm{g} / \mathrm{L}) & (\mu \mathrm{g} / \mathrm{L}) & (\mu \mathrm{g} / \mathrm{L}) & (\mu \mathrm{g} / \mathrm{L}) & \text { post-SSA } & \text { index } & \text { index } & \text { volume } & \text { volume }\end{array}$ $(\mu \mathrm{g} / \mathrm{L}) \quad(\mu \mathrm{g} / \mathrm{L})$ pre-SSA post-SSA pre-SSA post-SSA

\begin{tabular}{|c|c|c|c|c|c|c|c|c|c|c|c|c|c|c|c|c|}
\hline & & & & & & & & & & & & & & & $\left(\mathrm{cm}^{3}\right)$ & $\left(\mathrm{cm}^{3}\right)$ \\
\hline 1 & $\mathrm{M}$ & 27 & LAN & 9.12 & 9.85 & 2.31 & 1.73 & 1.92 & 2.35 & 2.69 & 3.65 & 8.88 & 2.41 & 2.50 & 1.99 & 1.66 \\
\hline 2 & $\mathrm{~F}$ & 51 & OCT & 17.73 & 37.23 & 2.19 & 0.77 & 0.58 & 0.46 & 0.50 & 0.50 & 2.18 & 4.98 & 1.12 & 1.84 & 0.90 \\
\hline 3 & M & 51 & OCT & 31.42 & 29.62 & 12.50 & 8.54 & 8.65 & 12.04 & 11.31 & 13.46 & 8.74 & 2.71 & 2.07 & 7.19 & 7.17 \\
\hline 4 & $\mathrm{~F}$ & 38 & LAN & 123.24 & 31.85 & 4.38 & 3.00 & 4.58 & 8.08 & 13.31 & 18.92 & 4.33 & - & 2.19 & 2.08 & 1.53 \\
\hline 5 & F & 28 & OCT & 86.15 & 96.92 & 38.35 & 29.00 & 28.31 & 33.81 & 27.35 & 42.31 & 91.38 & 2.35 & 2.09 & 11.35 & 11.62 \\
\hline 6 & M & 34 & OCT & 31.58 & 13.42 & 1.62 & 0.92 & 0.73 & 0.73 & 0.65 & 0.96 & 7.00 & 3.17 & 2.44 & 3.35 & 2.01 \\
\hline 7 & $\mathrm{~F}$ & 47 & OCT & 20.78 & 20.04 & 1.85 & 0.88 & 0.92 & 1.35 & 2.35 & 4.12 & 3.59 & 2.37 & 1.60 & 0.99 & 0.68 \\
\hline 8 & M & 45 & LAN & 10.87 & 18.38 & 1.12 & 0.69 & 0.77 & 0.69 & 1.08 & 1.27 & 1.53 & 3.02 & 1.58 & 0.60 & 0.40 \\
\hline 9 & $\mathrm{~F}$ & 33 & LAN & 39.24 & 36.04 & 8.42 & 7.77 & 9.54 & 13.00 & 11.19 & 15.38 & 48.45 & 2.84 & 2.25 & 2.46 & 2.25 \\
\hline 10 & F & 39 & OCT & 43.15 & 22.42 & 1.42 & 0.92 & 1.00 & 1.65 & 1.96 & 3.46 & 11.74 & 2.83 & 1.67 & 1.90 & 1.72 \\
\hline 11 & M & 54 & LAN & 86.08 & 71.92 & 22.85 & 17.65 & 22.42 & 24.19 & 16.58 & 25.81 & 59.77 & 2.26 & 2.25 & 15.55 & 14.06 \\
\hline 12 & F & 31 & OCT & 33.75 & 30.88 & 13.88 & 12.96 & 16.08 & 16.58 & 18.46 & 24.31 & 33.27 & 2.55 & 2.34 & 6.80 & 6.53 \\
\hline 13 & F & 41 & OCT & 53.38 & 55.77 & 25.81 & 20.23 & 30.23 & 37.73 & 46.15 & 45.00 & 28.56 & 3.48 & 2.30 & 9.01 & 8.49 \\
\hline 14 & F & 28 & OCT & 132.69 & 96.54 & 8.96 & 2.58 & 2.12 & 2.38 & 3.27 & 4.92 & 1.11 & 3.07 & 0.61 & 5.54 & 3.30 \\
\hline 15 & M & 17 & OCT & 49.69 & 54.62 & 26.69 & 35.35 & 35.96 & 53.08 & 46.54 & 40.38 & 69.46 & 2.15 & 1.04 & 51.30 & 48.46 \\
\hline 16 & $\mathrm{~F}$ & 44 & OCT & 71.23 & 65.38 & 13.08 & 2.77 & 1.73 & 1.15 & 0.77 & 1.04 & 5.60 & 2.07 & 1.57 & 2.39 & 1.20 \\
\hline 17 & F & 25 & LAN & 31.21 & 20.85 & 4.35 & 2.58 & 1.88 & 2.08 & 3.35 & 4.50 & 9.49 & 2.59 & 1.96 & 5.90 & 3.53 \\
\hline 18 & M & 57 & LAN & 16.62 & 13.12 & 2.73 & 1.50 & 1.19 & 0.88 & 1.27 & 1.31 & 14.24 & 3.77 & 2.66 & 1.71 & 1.41 \\
\hline 19 & $\mathrm{~F}$ & 65 & LAN & 3.32 & 2.50 & 0.65 & 0.88 & 1.19 & 2.31 & 2.35 & 2.88 & 3.10 & 3.07 & 2.34 & 0.78 & 0.52 \\
\hline 20 & M & 31 & LAN & 26.12 & 20.23 & 8.92 & 5.50 & 6.00 & 4.00 & 5.42 & 6.08 & 23.16 & 3.65 & 2.96 & 5.34 & 5.41 \\
\hline 21 & $\mathrm{~F}$ & 60 & LAN & 13.88 & 11.12 & 2.62 & 3.35 & 3.42 & 4.62 & 5.35 & 8.81 & 7.38 & 2.27 & 1.96 & 1.02 & 0.84 \\
\hline 22 & M & 36 & LAN & 27.98 & 31.00 & 5.08 & 2.96 & 3.35 & 3.65 & 2.46 & 2.85 & 14.54 & 3.83 & 3.67 & 0.81 & 0.48 \\
\hline 23 & $\mathrm{~F}$ & 68 & OCT & 89.62 & 95.00 & 10.62 & 18.50 & 8.85 & 6.92 & 7.88 & 41.92 & 12.91 & 2.44 & 1.63 & 4.91 & 3.31 \\
\hline 24 & F & 65 & OCT & 32.17 & 28.50 & 5.69 & 2.08 & 1.92 & 1.73 & 1.96 & 2.15 & 3.21 & 2.47 & - & 2.23 & 1.74 \\
\hline 25 & F & 59 & OCT & 77.31 & 106.15 & 74.62 & 56.92 & 90.00 & 96.15 & 91.92 & 84.23 & 76.92 & 3.25 & 2.89 & 1.99 & 1.88 \\
\hline 26 & F & 42 & OCT & 33.79 & 32.27 & 17.88 & 6.00 & 6.08 & 5.58 & 6.88 & 9.88 & 7.92 & 3.70 & 2.52 & 5.09 & 4.56 \\
\hline 27 & F & 45 & OCT & 40.72 & 10.42 & 1.15 & 0.88 & 0.85 & 0.81 & 0.77 & 0.92 & 3.59 & 2.66 & 1.62 & 1.81 & 1.19 \\
\hline 28 & F & 44 & OCT & 16.70 & 22.42 & 11.27 & 13.00 & 9.81 & 11.12 & 14.15 & 12.85 & 17.18 & 2.70 & 2.49 & 7.16 & 5.28 \\
\hline 29 & M & 60 & LAN & 12.65 & 11.19 & 1.12 & 0.50 & 0.42 & 0.35 & 0.31 & 0.38 & 1.16 & 3.19 & 1.13 & - & - \\
\hline 30 & M & 43 & OCT & 43.50 & 57.31 & 13.00 & 4.73 & 3.00 & 2.04 & 2.42 & 2.19 & 10.61 & - & 2.22 & 4.86 & 3.84 \\
\hline 31 & M & 61 & LAN & 35.71 & 43.46 & 18.00 & 18.12 & 20.85 & 19.31 & 20.77 & 25.04 & 26.37 & - & 2.92 & 12.18 & 12.42 \\
\hline 32 & M & 38 & LAN & 110.38 & 127.31 & 50.38 & 57.31 & 55.77 & 63.08 & 55.77 & 65.00 & 78.69 & 5.63 & 4.29 & 9.21 & 8.06 \\
\hline 33 & F & 30 & OCT & 22.61 & 14.42 & 6.96 & 5.35 & 5.69 & 6.27 & 7.65 & 9.85 & 7.59 & 3.06 & 2.46 & 2.26 & 1.24 \\
\hline 34 & F & 34 & LAN & 77.15 & 76.92 & 23.04 & 18.27 & 19.85 & 19.50 & 21.50 & 26.38 & 43.43 & 2.21 & 1.43 & 4.42 & 4.42 \\
\hline 35 & F & 55 & OCT & 3.79 & 3.38 & 1.65 & 2.04 & 2.88 & 2.62 & 3.08 & 3.65 & 3.42 & 3.35 & 2.28 & 6.27 & 6.26 \\
\hline 36 & M & 47 & OCT & 23.27 & 23.27 & 1.42 & 0.54 & 0.88 & 0.73 & 0.62 & 0.73 & 2.56 & 4.63 & 3.14 & 0.49 & 0.38 \\
\hline 37 & $\mathrm{~F}$ & 34 & LAN & 60.89 & 43.46 & 4.04 & 2.00 & 0.85 & 1.08 & 1.46 & 3.04 & 4.25 & 2.04 & 0.64 & 1.71 & 1.18 \\
\hline 38 & F & 34 & LAN & 25.88 & 24.73 & 6.85 & 6.23 & 5.69 & 11.65 & 13.12 & 4.92 & 15.54 & 1.68 & 1.73 & 4.61 & 4.51 \\
\hline 39 & F & 61 & OCT & 46.92 & 53.46 & 5.88 & 1.85 & 1.23 & 1.73 & 1.42 & 0.65 & 1.85 & 3.53 & 0.64 & 1.03 & 0.57 \\
\hline 40 & F & 57 & OCT & 11.43 & 12.88 & 1.19 & 0.73 & 0.27 & 0.88 & 0.77 & 0.54 & 2.06 & 3.28 & 1.34 & 1.44 & 0.80 \\
\hline 41 & F & 56 & OCT & 37.92 & 36.88 & 3.69 & 1.27 & 0.62 & 0.88 & 0.88 & 1.81 & 2.92 & 4.37 & 1.76 & 2.04 & 1.15 \\
\hline 42 & F & 17 & OCT & 10.50 & 11.77 & 15.04 & 16.46 & 23.04 & 12.54 & 8.19 & 7.23 & 6.13 & 1.18 & 1.35 & 15.49 & 14.57 \\
\hline 43 & F & 19 & OCT & 114.08 & 65.00 & 34.58 & 49.23 & 64.23 & 51.92 & 50.77 & 66.54 & 79.69 & 1.70 & 1.33 & 28.59 & 28.17 \\
\hline 44 & F & 32 & OCT & 8.80 & 6.54 & 0.81 & 0.54 & 0.50 & 0.54 & 0.73 & 0.69 & 1.10 & 1.66 & 0.68 & 0.42 & 0.33 \\
\hline 45 & M & 39 & OCT & 94.77 & 86.15 & 17.88 & 6.19 & 4.15 & 3.46 & 3.46 & 3.27 & 1.44 & 4.99 & 0.65 & 3.10 & 1.98 \\
\hline 46 & M & 35 & OCT & 54.62 & 52.69 & 17.19 & 10.42 & 12.50 & 11.27 & 10.54 & 13.42 & 47.46 & 3.13 & 3.21 & 20.21 & 13.01 \\
\hline 47 & F & 35 & OCT & 11.42 & 9.62 & 1.15 & 0.73 & 0.69 & 0.88 & 1.00 & 1.27 & 1.18 & 2.09 & 1.50 & 2.47 & 1.60 \\
\hline 48 & M & 56 & OCT & 18.85 & 19.58 & 1.81 & 2.19 & 1.92 & 1.65 & 1.81 & 3.31 & 3.62 & 2.74 & 2.00 & 7.40 & 2.83 \\
\hline 49 & F & 38 & OCT & 21.81 & 27.08 & 3.81 & 1.54 & 1.35 & 1.23 & 2.04 & 2.31 & 2.57 & 3.11 & 1.31 & 1.41 & 0.79 \\
\hline 50 & M & 41 & LAN & 70.23 & 74.62 & 7.92 & 2.12 & 1.08 & 0.81 & 0.58 & 0.58 & 6.10 & 3.40 & 1.96 & 2.59 & 1.42 \\
\hline 51 & F & 33 & OCT & 126.00 & 107.69 & 22.92 & 8.00 & 5.46 & 4.31 & 4.00 & 6.31 & 5.33 & 3.73 & 1.28 & 5.88 & 2.88 \\
\hline 52 & F & 31 & LAN & 24.42 & 22.85 & 3.54 & 3.92 & 5.73 & 9.46 & 14.96 & 23.38 & 23.05 & 2.02 & 1.88 & 1.85 & 1.36 \\
\hline 53 & F & 54 & OCT & 6.54 & 6.62 & 2.42 & 2.08 & 2.23 & 2.23 & 2.04 & 2.15 & 2.60 & 3.18 & 2.24 & 2.24 & 2.51 \\
\hline 54 & M & 41 & OCT & 15.69 & 7.15 & 1.12 & 0.65 & 0.58 & 0.50 & 0.50 & 0.42 & 0.65 & 2.19 & 0.76 & 0.89 & 0.89 \\
\hline 55 & $\mathrm{~F}$ & 42 & OCT & 6.12 & 7.65 & 2.19 & 2.50 & 2.81 & 3.54 & 3.46 & 3.88 & 3.02 & 2.33 & 1.74 & 2.88 & 2.51 \\
\hline 56 & F & 36 & OCT & 16.65 & 12.81 & 3.73 & 3.46 & 4.92 & 6.27 & 7.77 & 11.38 & 7.92 & 2.79 & 1.84 & 5.22 & 4.46 \\
\hline 57 & F & 33 & LAN & 56.15 & 79.23 & 25.00 & 18.73 & 16.19 & 12.35 & 8.31 & 8.08 & 15.04 & 1.95 & 2.68 & 4.17 & 3.52 \\
\hline
\end{tabular}


Supplementary Table 2 Cont.

\begin{tabular}{|c|c|c|c|c|c|c|c|c|c|c|c|c|c|c|c|c|}
\hline $\begin{array}{l}\text { Patient: } \\
\text { (no.) }\end{array}$ & Sex & $\begin{array}{l}\text { Age } \\
(\mathrm{y})\end{array}$ & SSA $^{*}$ & $\begin{array}{c}\mathrm{GH}_{\text {mean }} \\
\text { pre-SSA } \\
(\mu \mathrm{g} / \mathrm{L})\end{array}$ & $\begin{array}{c}\mathrm{GH} 0 \\
(\mu \mathrm{g} / \mathrm{L})\end{array}$ & $\begin{array}{c}\mathrm{GH} 1 \\
(\mu \mathrm{g} / \mathrm{L})\end{array}$ & $\begin{array}{c}\mathrm{GH} 2 \\
(\mu \mathrm{g} / \mathrm{L})\end{array}$ & $\begin{array}{c}\mathrm{GH} 3 \\
(\mu \mathrm{g} / \mathrm{L})\end{array}$ & $\begin{array}{c}\mathrm{GH} 4 \\
(\mu \mathrm{g} / \mathrm{L})\end{array}$ & $\begin{array}{c}\mathrm{GH} 5 \\
(\mu \mathrm{g} / \mathrm{L})\end{array}$ & $\begin{array}{c}\mathrm{GH} 6 \\
(\mu \mathrm{g} / \mathrm{L})\end{array}$ & $\begin{array}{c}\mathrm{GH}_{\text {mean }} \\
\text { post-SSA } \\
(\mu \mathrm{g} / \mathrm{L})\end{array}$ & $\begin{array}{c}\text { IGF-1 } \\
\text { index } \\
\text { pre-SSA }\end{array}$ & $\begin{array}{c}\text { IGF-1 } \\
\text { index } \\
\text { post-SSA }\end{array}$ & $\begin{array}{c}\text { Tumor } \\
\text { volume } \\
\text { pre-SSA } \\
\left(\mathrm{cm}^{3}\right)\end{array}$ & $\begin{array}{c}\text { Tumor } \\
\text { volume } \\
\text { post-SSA } \\
\left(\mathrm{cm}^{3}\right)\end{array}$ \\
\hline 58 & $M$ & 44 & $\overline{\mathrm{OCT}}$ & 3.73 & 3.08 & 0.65 & 0.42 & 0.38 & 0.46 & 0.69 & 0.88 & 1.08 & 3.30 & 1.23 & 0.35 & 0.35 \\
\hline 59 & F & 60 & LAN & 16.69 & 21.92 & 8.85 & 8.73 & 7.27 & 9.23 & 12.31 & 18.54 & 9.52 & 3.49 & 3.59 & 0.53 & 0.49 \\
\hline 60 & M & 44 & LAN & 21.25 & 29.27 & 3.23 & 1.46 & 1.27 & 1.08 & 1.00 & 1.69 & 4.19 & 3.25 & 2.19 & 1.17 & 1.06 \\
\hline 61 & M & 52 & OCT & 37.35 & 25.73 & 4.81 & 2.85 & 2.81 & 2.88 & 3.00 & 3.65 & 4.01 & 4.95 & 3.23 & 2.04 & 1.44 \\
\hline 62 & M & 50 & OCT & 32.67 & 22.92 & 4.12 & 2.50 & 2.65 & 1.81 & 2.73 & 3.50 & 20.48 & 2.95 & 2.25 & 3.21 & 2.12 \\
\hline 63 & F & 50 & OCT & 40.27 & 33.19 & 21.31 & 27.96 & 30.08 & 32.46 & 35.12 & 36.15 & 34.05 & 2.35 & 2.11 & 1.52 & 1.88 \\
\hline 64 & $\mathrm{~F}$ & 32 & OCT & 67.69 & 56.54 & 29.85 & 43.08 & 47.31 & 60.00 & 52.69 & 51.54 & 50.00 & 2.37 & 1.90 & - & - \\
\hline 65 & $\mathrm{~F}$ & 50 & OCT & 17.65 & 12.27 & 1.46 & 0.54 & 0.46 & 0.58 & 0.62 & 1.00 & 0.41 & 2.41 & 1.13 & 1.12 & 0.75 \\
\hline 66 & $\mathrm{~F}$ & 54 & OCT & 21.08 & 16.58 & 5.12 & 4.19 & 4.73 & 5.88 & 6.77 & 9.69 & 3.15 & 2.50 & 2.50 & 4.00 & 3.48 \\
\hline 67 & $\mathrm{~F}$ & 41 & LAN & 18.32 & 22.00 & 5.58 & 2.81 & 2.35 & 2.19 & 2.23 & 2.77 & 1.72 & 3.04 & 2.74 & 6.77 & 5.54 \\
\hline
\end{tabular}

* LAN: lanreotide SR, 40 mg/2 weeks $\times 12$ weeks; OCT: octreotide LAR, 20 mg/4 weeks $\times 12$ weeks.

Supplementary Table 3 The correlation analysis between the 9 parameters and the reduction in $\mathrm{GH}_{\mathrm{m}}$, IGF- 1 and tumor size $(r$ and $p$ )

\begin{tabular}{|c|c|c|c|c|c|c|}
\hline & \multicolumn{2}{|c|}{$\mathrm{GH}_{\mathrm{m}}$ reduction } & \multicolumn{2}{|c|}{ IGF-1 reduction } & \multicolumn{2}{|c|}{ tumor size reduction } \\
\hline & $r$ & $p$ & $r$ & $p$ & $r$ & $p$ \\
\hline $\mathrm{GH}_{\mathrm{n}}$ & -0.538 & $0.000^{*}$ & -0.250 & 0.410 & -0.434 & 0.000 * \\
\hline$\Delta \mathrm{GH} 1$ & 0.705 & $0.000 *$ & 0.440 & $0.000 *$ & 0.649 & $0.000 *$ \\
\hline$\Delta \mathrm{GH} 2$ & 0.704 & $0.000 *$ & 0.445 & $0.000 *$ & 0.605 & $0.000 *$ \\
\hline $\operatorname{AUC}_{(0-6 \mathrm{~h})}$ & -0.479 & $0.000 *$ & -0.218 & 0.077 & -0.368 & $0.003 *$ \\
\hline$\triangle \mathrm{AUC1}$ & 0.670 & $0.000 *$ & 0.437 & $0.000 *$ & 0.586 & $0.000 *$ \\
\hline$\triangle \mathrm{AUC2}$ & 0.665 & $0.000 *$ & 0.438 & $0.000 *$ & 0.535 & $0.000 *$ \\
\hline $\mathrm{AUC}_{(\mathrm{m}-6 \mathrm{~h})}$ & -0.465 & $0.000 *$ & -0.213 & 0.084 & -0.364 & $0.003 *$ \\
\hline$\triangle \mathrm{AUC1}$ & 0.626 & $0.000 *$ & 0.428 & $0.000 *$ & 0.572 & $0.000 *$ \\
\hline$\triangle \mathrm{AUC2}$ & 0.672 & $0.000^{*}$ & 0.445 & $0.000 *$ & 0.554 & 0.000 * \\
\hline
\end{tabular}

$* p<0.05$

Supplementary Table 4 Results from linear regression analysis with the percentage of $\mathrm{GH}_{\mathrm{m}}$ reduction after 3 months treatment with SSA as dependent variable

\begin{tabular}{|c|c|c|c|c|c|c|c|c|c|c|c|c|}
\hline \multirow[b]{3}{*}{$\overline{\mathrm{GH}_{\mathrm{n}}}$} & \multicolumn{6}{|c|}{ Unadjusted estimates } & \multicolumn{6}{|c|}{ Adjusted estimates } \\
\hline & \multirow{2}{*}{$\begin{array}{c}\text { Beta } \\
-0.538\end{array}$} & \multirow{2}{*}{$\begin{array}{c}\frac{\mathrm{R}^{2}}{0.289} \\
\end{array}$} & \multirow{2}{*}{$\begin{array}{c}\text { B } \\
-1.714\end{array}$} & \multicolumn{2}{|c|}{$95 \% \mathrm{CI}$} & \multirow{2}{*}{$\frac{P}{0.000^{*}}$} & \multirow{2}{*}{$\begin{array}{r}\text { Beta } \\
-0.517\end{array}$} & \multirow{2}{*}{$\frac{\mathrm{R}^{2}}{0.311}$} & \multirow{2}{*}{$\frac{B}{-1.648}$} & \multicolumn{2}{|c|}{$95 \% \mathrm{CI}$} & \multirow{2}{*}{$\frac{P}{0.000^{*}}$} \\
\hline & & & & -2.379 & -1.048 & & & & & -2.323 & -0.973 & \\
\hline$\Delta \mathrm{GH} 1$ & 0.705 & 0.497 & 1.482 & 1.112 & 1.851 & 0.000 * & 0.721 & 0.538 & 1.517 & 1.144 & 1.889 & 0.000 * \\
\hline$\Delta \mathrm{GH} 2$ & 0.704 & 0.496 & 1.394 & 1.046 & 1.743 & 0.000 * & 0.711 & 0.539 & 1.408 & 1.064 & 1.753 & 0.000 * \\
\hline$\triangle \mathrm{AUC1}$ & 0.670 & 0.449 & 0.170 & 0.123 & 0.217 & 0.000 * & 0.706 & 0.501 & 0.179 & 0.132 & 0.227 & 0.000 * \\
\hline$\triangle \mathrm{AUC2}$ & 0.665 & 0.442 & 0.157 & 0.113 & 0.201 & 0.000 * & 0.682 & 0.492 & 0.161 & 0.118 & 0.205 & 0.000 * \\
\hline
\end{tabular}

$* p<0.05$

Supplementary Table 5 Optimal cutoff values of the 9 parameters in predicting a good IGF-1 response (Sensitivity, Specificity, PPV, NPV)

\begin{tabular}{|c|c|c|c|c|c|c|c|c|}
\hline & $\mathrm{AUC}^{* *}$ & Youden index & Cutoff value & Sensitivity (\%) & Specificity (\%) & PPV (\%) & NPV (\%) & $p$ \\
\hline$\overline{\mathrm{GH}_{\mathrm{n}}}$ & 0.813 & 0.517 & 0.67 & 91.7 & 60.0 & 69.2 & 88.0 & 0.000 * \\
\hline$\Delta \mathrm{GH} 1$ & 0.837 & 0.633 & $93.71 \%$ & 80.0 & 83.3 & 60.0 & 93.0 & $0.000 *$ \\
\hline$\Delta \mathrm{GH} 2$ & 0.817 & 0.659 & $94.15 \%$ & 86.7 & 79.2 & 56.5 & 95.0 & $0.000 *$ \\
\hline $\mathrm{AUC}_{(0-6 \mathrm{~h})}$ & 0.678 & 0.338 & $11.20 \%$ & 93.8 & 40.0 & 66.7 & 83.3 & 0.047 * \\
\hline$\triangle \mathrm{AUC1}$ & 0.833 & 0.659 & $-4.67 \%$ & 86.7 & 79.2 & 56.5 & 95.0 & $0.000 *$ \\
\hline$\triangle \mathrm{AUC2}$ & 0.796 & 0.600 & $-33.53 \%$ & 93.3 & 66.7 & 46.7 & 97.0 & $0.000 *$ \\
\hline $\mathrm{AUC}_{(\mathrm{m}-6 \mathrm{~h})}$ & 0.681 & 0.405 & 14.49 & 93.8 & 46.7 & 70.0 & 84.9 & $0.036^{*}$ \\
\hline$\triangle \mathrm{AUC1}$ & 0.813 & 0.592 & $-22.52 \%$ & 80.0 & 79.2 & 54.5 & 92.7 & $0.000^{*}$ \\
\hline$\triangle \mathrm{AUC} 2^{\prime}$ & 0.815 & 0.675 & $9.41 \%$ & 80.0 & 87.5 & 66.7 & 93.3 & 0.000 * \\
\hline
\end{tabular}

${ }^{*} p<0.05$. AUC ${ }^{* *}$, the area under the ROC curve. 


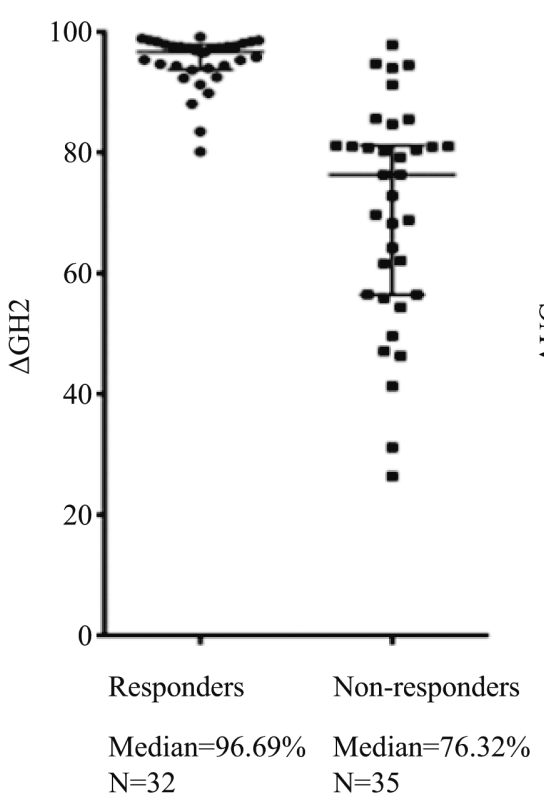

$p<0.0001$

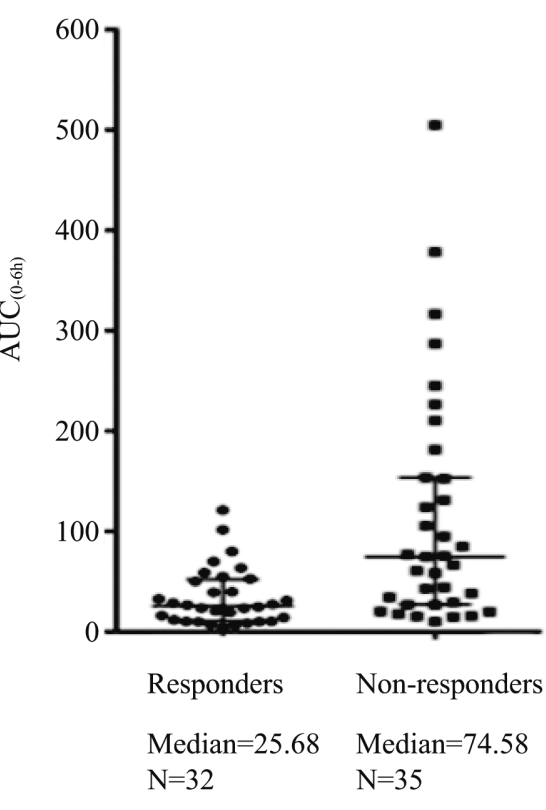

$p=0.0002$

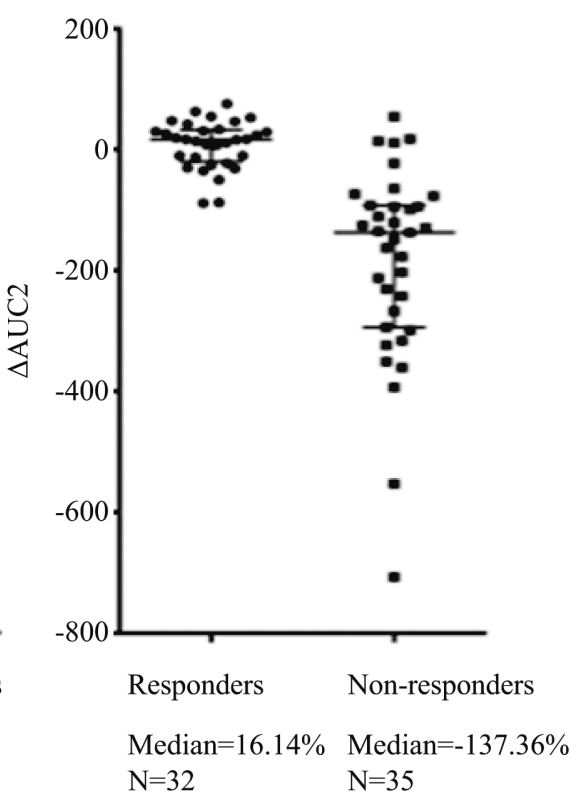

$p<0.0001$

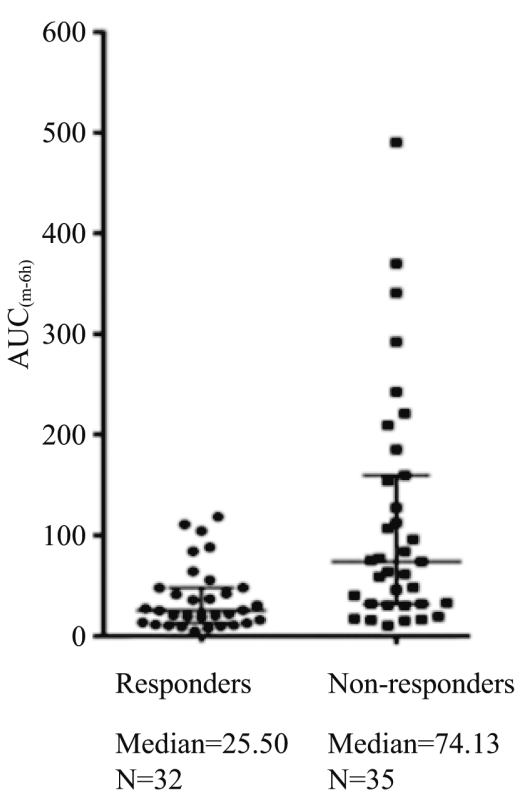

$p=0.0003$

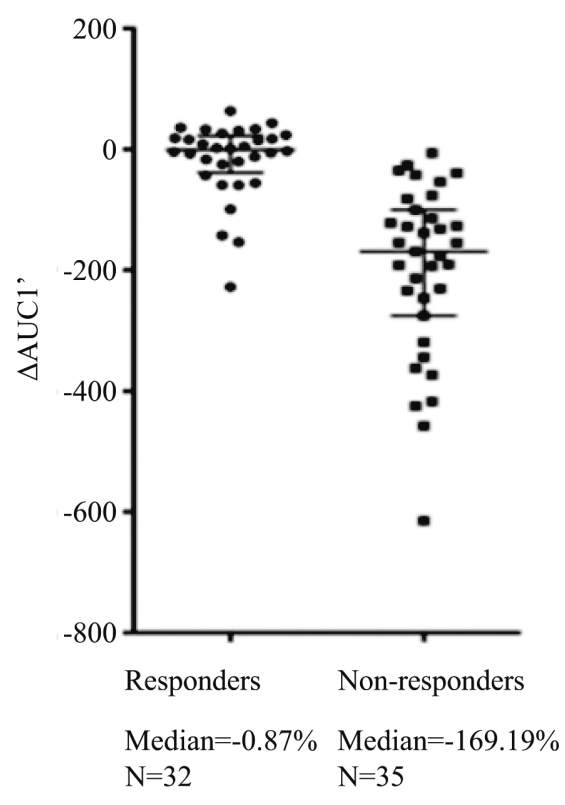

$p<0.0001$

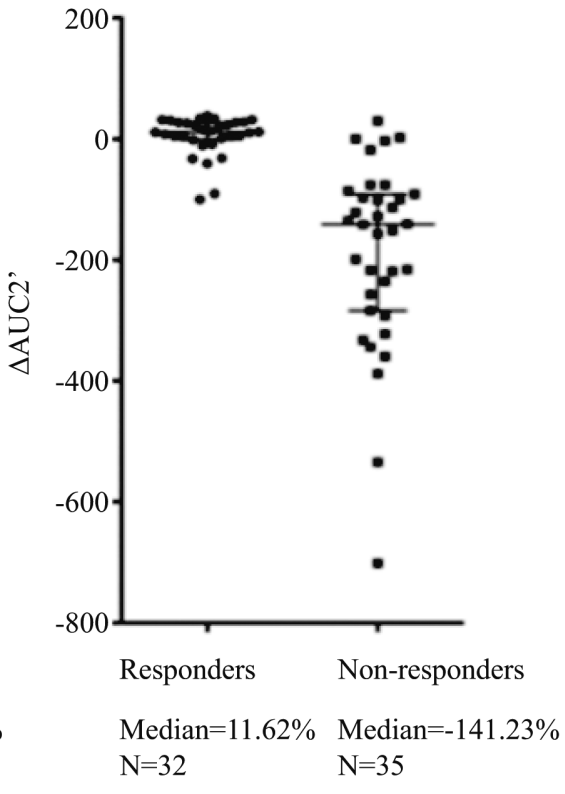

$p<0.0001$ 


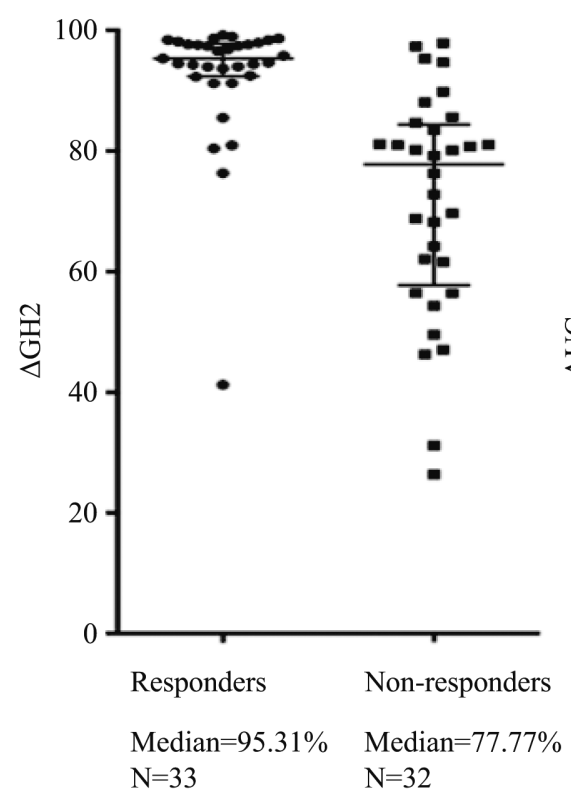

$p<0.0001$

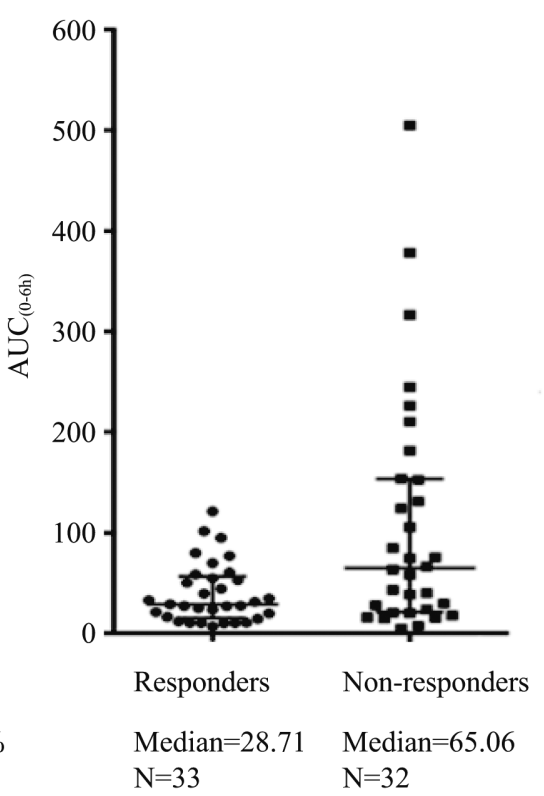

$p=0.0108$

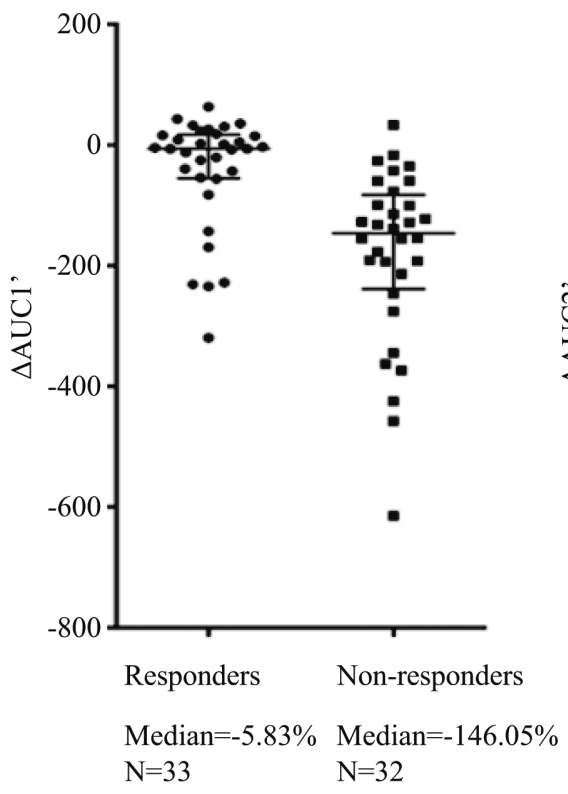

$p<0.0001$

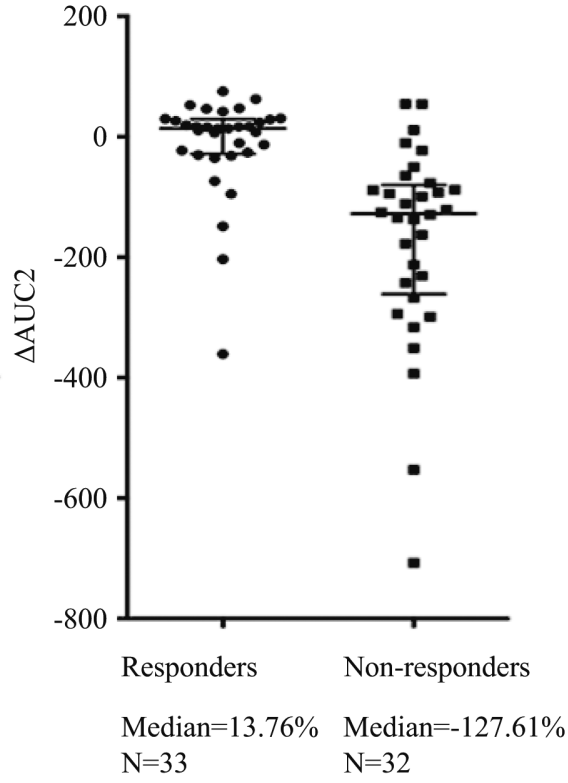

$p<0.0001$

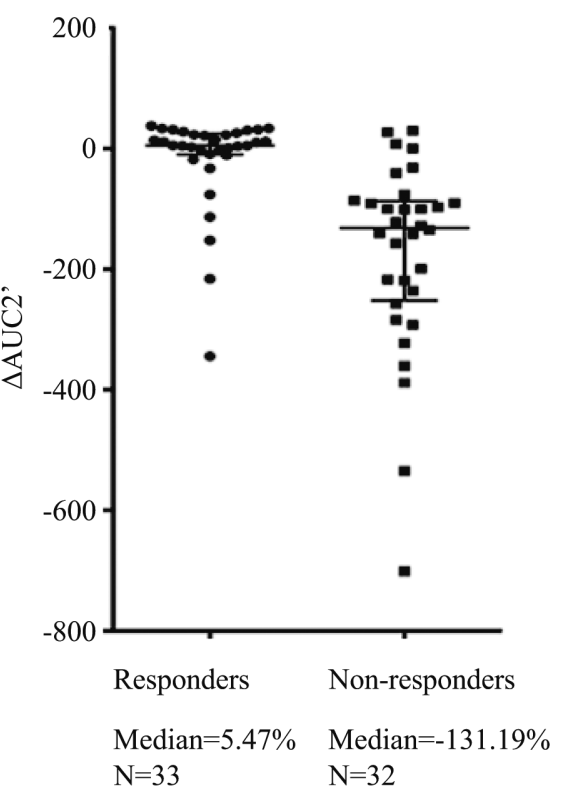

$p<0.0001$ 


\section{References}

1. Katznelson L, Atkinson JL, Cook DM, Ezzat SZ, Hamrahian AH, et al. (2011) American Association of Clinical Endocrinologists medical guidelines for clinical practice for the diagnosis and treatment of acromegaly --2011 update. Endocr Pract 17 Suppl 4: 1-44.

2. Abosch A, Tyrrell JB, Lamborn KR, Hannegan LT, Applebury CB, et al. (1998) Transsphenoidal microsurgery for growth hormone-secreting pituitary adenomas: initial outcome and long-term results. J Clin Endocrinol Metab 83: 3411-3418.

3. Bates AS, Van't Hoff W, Jones JM, Clayton RN (1993) An audit of outcome of treatment in acromegaly. $Q J$ Med 86: 293-299.

4. Melmed S, Colao A, Barkan A, Molitch M, Grossman $\mathrm{AB}$, et al. (2009) Guidelines for acromegaly management: an update. J Clin Endocrinol Metab 94: 1509-1517.

5. Melmed S, Jackson I, Kleinberg D, Klibanski A (1998) Current treatment guidelines for acromegaly. J Clin Endocrinol Metab 83: 2646-2652.

6. Mercado M, Borges F, Bouterfa H, Chang TC, Chervin A, et al. (2007) A prospective, multicentre study to investigate the efficacy, safety and tolerability of octreotide LAR (long-acting repeatable octreotide) in the primary therapy of patients with acromegaly. Clin Endocrinol (Oxf) 66: 859-868.

7. Carlsen SM, Svartberg J, Schreiner T, Aanderud S, Johannesen O, et al. (2011) Six-month preoperative octreotide treatment in unselected, de novo patients with acromegaly: effect on biochemistry, tumour volume, and postoperative cure. Clin Endocrinol (Oxf) 74: 736-743.

8. Sheppard M, Bronstein MD, Freda P, Serri O, De Marinis L, et al. (2015) Pasireotide LAR maintains inhibition of GH and IGF-1 in patients with acromegaly for up to 25 months: results from the blinded extension phase of a randomized, double-blind, multicenter, Phase III study. Pituitary 18: 385-394.

9. Colao A, Auriemma RS, Pivonello R (2016) The effects of somatostatin analogue therapy on pituitary tumor volume in patients with acromegaly. Pituitary 19: 210-221.

10. Lamberts SW, Uitterlinden P, Schuijff PC, Klijn JG (1988) Therapy of acromegaly with sandostatin: the predictive value of an acute test, the value of serum somatomedin- $\mathrm{C}$ measurements in dose adjustment and the definition of a biochemical 'cure'. Clin Endocrinol (Oxf) 29: 411-420.

11. Lamberts SWJ, van der Lely A-J, de Herder WW, Hofland LJ (1996) Octreotide. N Engl J Med 334: 246-254.

12. Pokrajac A, Claridge AG, Shakoor SK, Trainer PJ (2006) The octreotide test dose is not a reliable predictor of the subsequent response to somatostatin analogue therapy in patients with acromegaly. Eur J Endocrinol
154: 267-274.

13. Karavitaki N, Botusan I, Radian S, Coculescu M, Turner HE, et al. (2005) The value of an acute octreotide suppression test in predicting long-term responses to depot somatostatin analogues in patients with active acromegaly. Clin Endocrinol (Oxf) 62: 282-288.

14. Biermasz NR, Pereira AM, Smit JW, Romijn JA, Roelfsema F (2005) Intravenous octreotide test predicts the long term outcome of treatment with octreotidelong-acting repeatable in active acromegaly. Growth Horm IGF Res 15: 200-206.

15. Lindsay JR, McConnell EM, Hunter SJ, McCance DR, Sheridan B, et al. (2004) Poor responses to a test dose of subcutaneous octreotide predict the need for adjuvant therapy to achieve 'safe' growth hormone levels. Pituitary 7: 139-144.

16. Fougner SL, Bollerslev J, Svartberg J, Oksnes M, Cooper J, et al. (2014) Preoperative octreotide treatment of acromegaly: long-term results of a randomised controlled trial. Eur J Endocrinol 171: 229-235.

17. Colao A, Ferone D, Lastoria S, Marzullo P, Cerbone G, et al. (1996) Prediction of efficacy of octreotide therapy in patients with acromegaly. J Clin Endocrinol Metab 81: 2356-2362.

18. Heck A, Emblem KE, Casar-Borota O, Bollerslev J, Ringstad G (2015) Quantitative analyses of T2-weighted MRI as a potential marker for response to somatostatin analogs in newly diagnosed acromegaly. Endocrine 52: 333-343.

19. Ferone D, de Herder WW, Pivonello R, Kros JM, van Koetsveld PM, et al. (2008) Correlation of in vitro and in vivo somatotropic adenoma responsiveness to somatostatin analogs and dopamine agonists with immunohistochemical evaluation of somatostatin and dopamine receptors and electron microscopy. J Clin Endocrinol Metab 93: 1412-1417.

20. Caron PJ, Bevan JS, Petersenn S, Flanagan D, Tabarin A, et al. (2014) Tumor shrinkage with lanreotide Autogel $120 \mathrm{mg}$ as primary therapy in acromegaly: results of a prospective multicenter clinical trial. J Clin Endocrinol Metab 99: 1282-1290.

21. Annamalai AK, Webb A, Kandasamy N, Elkhawad M, Moir S, et al. (2013) A comprehensive study of clinical, biochemical, radiological, vascular, cardiac, and sleep parameters in an unselected cohort of patients with acromegaly undergoing presurgical somatostatin receptor ligand therapy. J Clin Endocrinol Metab 98: 1040-1050.

22. Plockinger U, Quabbe HJ (2005) Presurgical octreotide treatment in acromegaly: no improvement of final growth hormone $(\mathrm{GH})$ concentration and pituitary function. A long-term case-control study. Acta Neurochir (Wien) 147: 485-493. 
23. Puig-Domingo M, Resmini E, Gomez-Anson B, Nicolau $\mathrm{J}$, Mora M, et al. (2010) Magnetic resonance imaging as a predictor of response to somatostatin analogs in acromegaly after surgical failure. J Clin Endocrinol Metab 95: 4973-4978.

24. Potorac I, Petrossians P, Daly AF, Schillo F, Ben Slama C, et al. (2015) Pituitary MRI characteristics in 297 acromegaly patients based on T2-weighted sequences. Endocr Relat Cancer 22: 169-177.

25. Colao A, Auriemma RS, Lombardi G, Pivonello R (2011) Resistance to somatostatin analogs in acromegaly. Endocr Rev 32: 247-271.

26. Gadelha MR, Kasuki L, Korbonits M (2013) Novel pathway for somatostatin analogs in patients with acromegaly. Trends Endocrinol Metab 24: 238-246.

27. Jenkins PJ, Emery M, Howling SJ, Evanson J, Besser GM, et al. (2004) Predicting therapeutic response and degree of pituitary tumour shrinkage during treatment of acromegaly with octreotide LAR. Horm Res 62: 227-232.

28. Halah FP, Elias LL, Martinelli CE Jr, Castro M, Moreira AC (2004) [Usefulness of subcutaneous or long-acting octreotide as a predictive test and in the treatment of acromegaly]. Arq Bras Endocrinol Metabol 48: 245-252.

29. Gilbert JA, Miell JP, Chambers SM, McGregor AM, Aylwin SJ (2005) The nadir growth hormone after an octreotide test dose predicts the long-term efficacy of somatostatin analogue therapy in acromegaly. Clin Endocrinol (Oxf) 62: 742-747.

30. Halperin I, Nicolau J, Casamitjana R, Sesmilo G, SerraPrat M, et al. (2008) A short acute octreotide test for response prediction of long-term treatment with somatostatin analogues in acromegalic patients. Horm Metab Res 40: 422-426.

31. Bandgar TR, Sarathi V, Shivane V, Bansode N, Menon PS, et al. (2010) The value of an acute octreotide suppression test in predicting response to long-term somatostatin analogue therapy in patients with acromegaly. $J$ Postgrad Med 56: 7-11.

32. de Herder WW, Taal HR, Uitterlinden P, Feelders RA, Janssen JA, et al. (2005) Limited predictive value of an acute test with subcutaneous octreotide for long-term IGF-I normalization with Sandostatin LAR in acromegaly. Eur J Endocrinol 153: 67-71.

33. Shen M, Shou X, Wang Y, Zhang Z, Wu J, et al. (2010) Effect of presurgical long-acting octreotide treatment in acromegaly patients with invasive pituitary macroadenomas: a prospective randomized study. Endocr $J$ 57: 1035-1044.

34. Heck A, Ringstad G, Fougner SL, Casar-Borota O, Nome T, et al. (2012) Intensity of pituitary adenoma on T2-weighted magnetic resonance imaging predicts the response to octreotide treatment in newly diagnosed acromegaly. Clin Endocrinol (Oxf) 77: 72-78. 